Portland State University

PDXScholar

7-31-1981

\title{
Cadmium and Zinc Levels in the Hair of Smokers and Nonsmokers
}

Neal R. Simonsen

Portland State University

Follow this and additional works at: https://pdxscholar.library.pdx.edu/open_access_etds

Part of the Biology Commons, and the Pharmacology, Toxicology and Environmental Health Commons

Let us know how access to this document benefits you.

\section{Recommended Citation}

Simonsen, Neal R., "Cadmium and Zinc Levels in the Hair of Smokers and Nonsmokers" (1981). Dissertations and Theses. Paper 3091.

https://doi.org/10.15760/etd.3084

This Thesis is brought to you for free and open access. It has been accepted for inclusion in Dissertations and Theses by an authorized administrator of PDXScholar. Please contact us if we can make this document more accessible: pdxscholar@pdx.edu. 
AN ABSTRACT OF THE THESIS OF Neal R Simonsen for the Master of Science in Biology presented July 31, 1981.

Title: Cadmium and Zinc Levels in the Hair of Smokers and Nonsmokers. APPROVED BY MEMBERS OF JHE THESIS COMMITTEE:

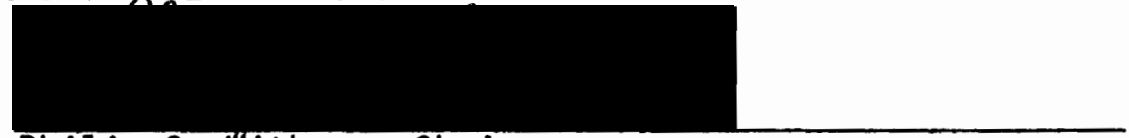

Philip C. Withers, Chairman

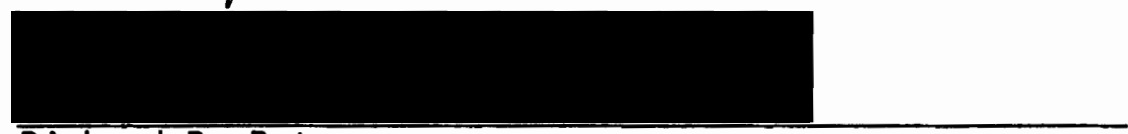

Richard R. Petersen

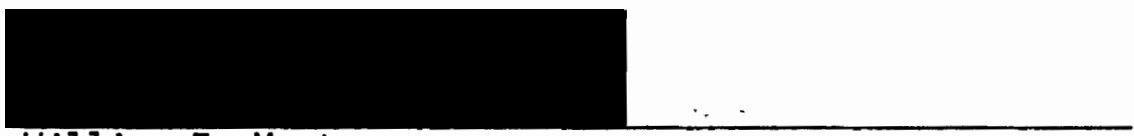

William E. Morton

To determine the relationship of tobacco and marijuana smoking to levels of cadmium and zinc manifested in hair samples, a study was conducted at Portland State University using atomic absorption spectrophotometry. 97 adult student volunteers participated in the main study.

Tobacco smokers had significantly higher hair cadmium concentrations and marijuana smokers had significantly higher zinc concentrations than nonsmokers, confirming tobacco smoking as a significant source of cadmium and implicating marijuana as a significant source of zinc. Higher average concentrations of cadmium among marijuana smokers and zinc among tobacco smokers were also observed but lacked statistical significance. Since cadmium is a toxic metal 
with a long biological half-life and a tendency to accumulate in certain target organs, particularly the kidney, the effects of smoking upon the level of long-term cadmium intake may have important consequences for health. In addition, comparative studies of hair metal levels neglecting to take smoking habits into account are suspect at least insofar as cadmium and probabiy zinc are concerned.

Trends toward increasing cadmium with age and observations of decreased cadmium among individuals with black hair and increased cadmium among individuals doing soldering are in general agreement with previous findings but the lack of significantly higher cadmium levels for males than for females contradicts previous work on Americans. Different proportions of smokers in the subject populations may be involved in this disagreement.

Former smokers had cadmium and $z$ inc concentrations that did not exceed the average concentrations for nonsmokers, indicating that hair cadmium and zinc levels reflect exposure or intake rather than cumulative body burden. 


\title{
CADMIUM AND ZINC LEVELS IN THE HAIR OF SMOKERS AND NONSMOKERS
}

by

Neal R Simonsen

A thesis submitted in partial fulfillment of the requirements for the degree of

\author{
MASTER OF SCIENCE \\ in \\ BIOLOGY
}

Portland State University 
TO THE OFFICE OF GRADUATE STUDIES AND RESEARCH:

The members of the Committee approve the thesis of Neal R Simonsen presented JuTy 31, 1981.

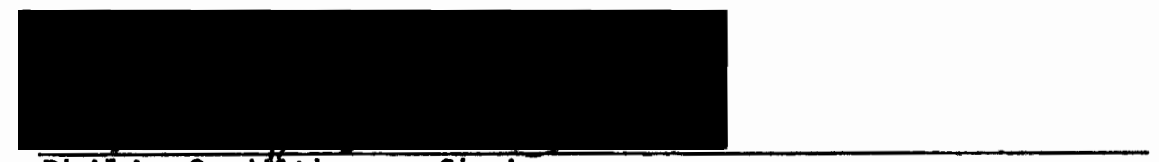

Phil ip C. Withers, Cha irman

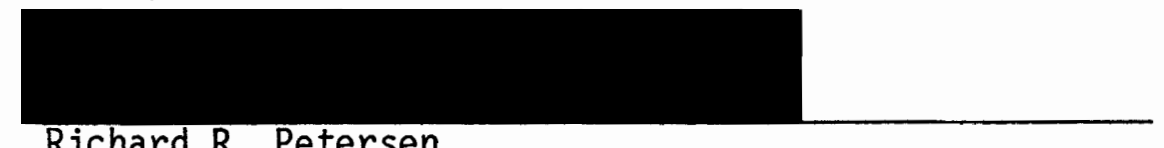

Richard R. Petersen

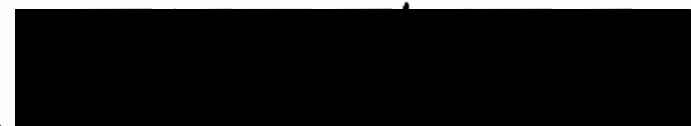

William E. Morton

APPROVED :

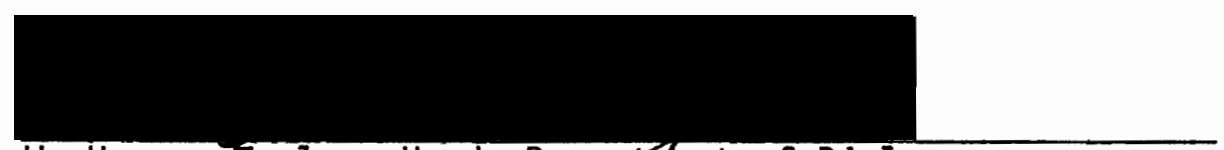

W. Herman Taylor, Head, Depactuent of Biology

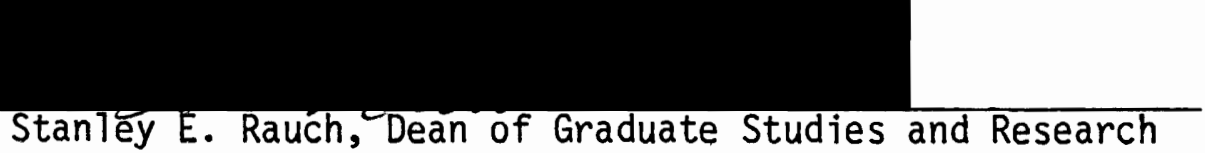




\section{ACKNOWLEDGEMENTS}

To the members of my thesis committee, for combining their expertise to aid and abet a project that didn't fall neatly into any one individual's field...

To Marilyn Petersen and Barbara Stewart, for sharing their experience in questionnaire design and statistical analysis, respectively . .

And to everyone who volunteered a piece of themselves to make this study possible . .

Thanks. 
TABLE OF CONTENTS

PAGE

ACKNOWLEDGEMENTS .............................. LIST OF TABLES ...................... . . . LIST OF FIGURES . . . . . . . . . . . . . . . vi vi LIST OF APPENDICES .......................... vii BACKGROUND .................................... 1 INTRODUCTION ................................. 10 MATERIALS AND METHODS .............................. 15 RESULTS ................................. 19

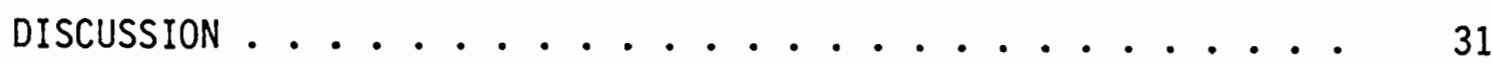

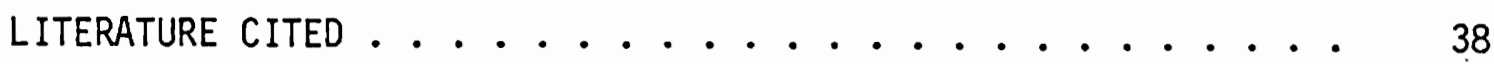
APPENDICES ............................... 47 


\section{LIST OF TABLES}

TABLE

PAGE

I Comparison of Hair Cadmium Levels and Current Smoking Habits--Pil ot Study .............

II Comparison of Hair Cadmium Levels and Current Smoking Habits--Ma in Study . . . . . . . . . .

III Comparison of Hair Zinc Levels and Current Smoking Habits ................

IV Comparison of Hair Cadmium Levels and Current Smoking Habits--Alternate Grouping, Ma in Study . . . . .

V Comparison of Hair Cadmium and Zinc Levels for Current,

Former and Non-Smokers ...........

VI Cadmium and Zinc Concentrations $(\mu \mathrm{g} / \mathrm{g})$ in $\mathrm{Ha}$ ir vs.

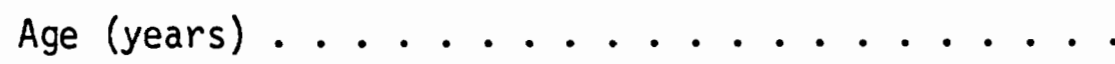

VII Differences in Hair Cadmium and Zinc Levels $(\mu \mathrm{g} / \mathrm{g})$

Associated with Miscellaneous Factors . . . . . .

VIII Hair Cadmium Concentrations $(\mu \mathrm{g} / \mathrm{g})$ for Individuals,

Grouped According to Smoking Habits . . . . . .

IX Hair Zinc Concentrations $(\mu \mathrm{g} / \mathrm{g})$ for Individuals,

Grouped According to Smoking Habits ....... 


\section{LIST OF FIGURES}

FIGURE

1. Cadmium Concentration in $\mathrm{Hair}(\mu \mathrm{g} / \mathrm{g})$ as a Function of Age (years) for Male and Female Nonsmokers . . . . 28

2. Cadmium Concentration in Hair $(\mu \mathrm{g} / \mathrm{g})$ as a Function of Body Weight (1bs) for Male and Female Nonsmokers . . 29 


\section{LIST OF APPENDICES}

APPENDIX

PAGE

A. Previous Studies on $\mathrm{Cd}$ and $\mathrm{Zn}$ in Human Hair.... 48

B. Informed Consent and Sample Questionnaire ..... 49

C. Hair Cadmium Concentrations $(\mu \mathrm{g} / \mathrm{g})$ for Individuals,

Grouped According to Smoking Habits . . . . . 52

D. Hair Zinc Concentrations $(\mu \mathrm{g} / \mathrm{g}$ ) for Individuals,

Grouped According to Smoking Habits ...... 53

E. Summary of Selected Questionnaire Responses--Ma in

Study ............... . . 54 
BACKGROUND

In 1817 Friedrich Strohmeyer isolated cadmium, a metallic element with an abundance in the earth's crust of less than one part per million. Although rare in nature, cadmium is usually closely associated with zinc, another member of group IIB of the periodic table with which it shares many properties. Unlike zinc, however, cadmium is highly toxic, a fact which was recognized about a century ago and has become more important as increasing refining of zinc and other metal ores and the discovery of an increasing variety of uses for cadmium has led to increased exposure to cadmium in the general as well as the industrial environment (Fasset and Irish 1978). The potential hazards of cadmium exposure to the general population began to draw wider interest after the implication of cadmium in a debilitating syndrome in Japan dubbed Itai-Itai or "ouch-ouch" in recognition of the agony associated with its characteristic bone deformation (osteomalacia) and greatly increased proneness to bone fracture. Consumption of contaminated rice grown in cadmium-rich waste water from a mining operation was cited as the primary cause for this disease (Flick et al. 1969; Nomiyama 1980). Since that time, much progress has been made in the investigation of potential health hazards of acute and chronic cadmium exposure.

The general effects of acute exposure to cadmium are well established: renal damage and dysfunction, osteoporosis, enteropathy and anemia, plus lung damage and dysfunction (i.e. pulmonary edema 
and interstitial pneumonitis) if exposure is via inhalation (DHEW 1977; Friberg et a1. 1974). The effects of chronic cadmium exposure are likely to be of much more importance to both industrial workers and the general population but are less well established. They may be characterized both by specific effects on normal metabolic pathway functions and more generalized health effects, as will be detailed.

Cadmium was tentatively linked to hypertension when Schroeder and Vinton (1962) described the development of hypertension in rats given small doses of cadmium in drinking water. Hypertension in response to cadmium was substantiated by two later studies (Schroeder 1964a; Schroeder and Buckman 1967a). A potential role of cadmium as a human hypertensive agent was indicated by Schroeder's (1964b) analysis of autopsy data collected by Tipton and Cook (1963) which indicated a presence of high cadmium-to-zinc ratios in cadavers of hypertensive subjects. Direct vasoconstriction and increased cardiac output were suggested as mechanisms for the induction of hypertension by cadmium, based again on experiments with rats (Perry et al. 1967). But in 1969 Morgan found no elevation of cadmium levels in kidneys or livers of hypertensive subjects and in an epidemiological study (Holden 1969) no increase in the incidence of hypertension was noted for subjects industrially exposed to cadmium. A link between cadmium and cardiovascular disease death rates in the general population was reported by Carroll (1966) with a marked correlation between those death rates and cadmium levels in the air of 28 U.S. cities, and reinforced by Hickey, Schoff and Clelland (1967) with similar findings for cadmium and vanadium levels in the air of 26 cities. This link 
was weakened in 1971 when Hunt et a1. found no association between cadmium in dustfall and cardiovascular disease rate in 77 cities, and criticized Carroll's study on the grounds that population density correlated more strongly than cadmium level with the death rate. More recently, cadmium in water supplies has been linked to coronary heart disease rates (Bierenbaum 1975), and in turn this 1 ink too has been disputed (Sharrett 1977). Animal experiments continue to demonstrate the induction of hypertension by cadmium (Perry et a 1. 1973; Doyle et al. 1975; Revis 1977; Perry et al. 1980), but the potential role of cadmium in human cardiovascular disease remains unsubstantiated.

The relationship of cadmium to emphysema also is unclear. Although a number of studies have found evidence for an association between chronic cadmium exposure and emphysema (Bonnel1 1955; Holden 1965; Lewis et a1. 1969), other studies have found no evidence for such an association (Suzuki et a 1. 1965; Lauwerys et al. 1974).

There is good experimental evidence for a teratogenic role of cadmium (Ferm et a1. 1969; Schroeder and Mitchener 1971; Chernoff 1973; Earl and Vish 1979) and mixed evidence for carcinogenic (Heath 1962; Gunn et a1. 1963; Schroeder et a1. 1964c; Gunn et a1. 1967; Shimkin et a1. 1978) and mutagenic (Epstein et a1. 1972; Sissoeff et al. 1976; Mitra and Bernstein 1978) roles in animals, and some epidemiological evidence for the involvement of cadmium in human cancer (Potts 1965; Lemen et a1. 1976). The importance of cadmium for the general population in regard to birth defects, mutations and cancer, however, remains to be established. 
Cadmium has also been shown to alter the immune response in experimental animals, particularly inhibiting the cellular component (Cook et al. 1975; Loose et a1. 1977; Muller et a1. 1979); whether this effect has significance for human health is unknown.

Associations of cadmium with some other disease conditions are more straightforward. Changes in renal function of chronically exposed workers have been observed repeatediy since Friberg (1948) found renal damage and proteinuria in workers exposed to cadmium dust. Studies verifying the association of cadmium with renal tubule damage and excretion of low molecular weight proteins (particularly $\mathrm{B}_{2}$ microglobulins) have been widespread (e.g. Clarkson and Kench 1956; Nogawa 1980). Effects of cadmium on bone structure have been found in a number of studies upon chronically exposed workers and experimentally exposed animals. These studies have been extensively reviewed by Friberg et a1. (1974) and Nomiyama (1980).

Cadmium metabolism is highly complex. The route of intake is of crucial importance to the impact of cadmium on the body. Cadmium retention is variable but potentially is of a very long-term nature and interactions with other metals and associated systems are myriad and marked (Prasad 1976).

Intraperitoneal and intravenous intake of cadmium are obviously of little significance under most circumstances despite the very high retention rates (over 90\%) reported for these routes (Moore et al. 1973). Oral intake of cadmium generally results in absorption of 3-5\% (Thomas 1980), although retention rate decreases with increasingly large doses (Moore et a1. 1973); retention rates of from $1.5 \%$ to $29 \%$ 
have been observed in humans (Nomiyama 1980). Intake of cadmium via inhalation, on the other hand, usually results in absorption of between $10 \%$ and $50 \%$ (Friberg et a1. 1974). Retention of inhaled cadmium is greatly influenced by the size of particles or form of chemical in which cadmium is inhaled (Nomiyama 1980). Retention of orally ingested cadmium is apparently not influenced by chemical form but is sensitive to dietary and physiological factors, e.g. calcium, protein, Vitamin D and zinc levels (Moore et al. 1973; Nomiyama 1980).

Experiments on animals suggest that cadmium, once absorbed, has a half-life of from 200 days for mice (Durbin et al. 1957) to 2 years for squirrel monkeys (Nordberg et al. 1971), with a tendency toward decreasing rates of decline with increasing time from exposure. Mathematical models based on excretion studies with humans project 10 to 30 year half-lives for whole body cadmium (Friberg et al. 1974). Recently, Travis and Haddock (1980) have suggested that the biological half-life of cadmium is age-dependent, declining from around 34 years at birth to 11 years at age 80 as a result of progressive renal change. Regardless of the exact biological half-life, cadmium interacts widely with other metal systems. The best known of these interactions involves zinc. Zinc is an essential mineral involved in many vital functions (Underwood 1971; Ochiai 1977). Cadmium has been characterized as an antimetabolite of zinc due to the inverse effect it exerts on such factors as growth, lymphocyte count and hemoglobin levels compared to zinc (Petering et al. 1971a). While cadmium seems to block many of the actions of zinc, the reverse is also true: thus, zinc has been shown to have a prophylactic effect against acute 
cadmium toxicity (Gunn et a1. 1968). Competition for protein binding sites in mucosal cells and tissues and zinc metalloenzymes is the accepted explanation for this behavior (Underwood 1979).

Cadmium also seems to strongly affect calcium metabolism. It is not clear, however, whether cadmium affects calcium metabol ism directly or indirectly: inhibition of 1-25 dihydrocholecalciferol synthesis (Feldman and Cousins 1973) or alkaline phosphatase activity (Ribas-Ozonas 1971) could affect bone by blocking intestinal calcium uptake or bone deposition, for example. Recent studies confirm a decrease in alkaline phosphatase activity in vivo, apparently induced by degeneration of renal cells containing alkaline phosphatase (Peereboom-Stegeman et a 1. 1979) and indicate a reduction in calcium binding.protein in the intestinal mucosa with dietary exposure to cadmium (Fullmer et a1. 1980), thus suggesting that cadmium interferes with calcium metabolism at both the intestinal and the kidney level. Cadmium may interfere with nerve transmission by binding to $\mathrm{Ca}^{+2}$ receptor sites and preventing $\mathrm{Ca}^{+2}$ influx from enhancing neurotransmitter release at the presynaptic nerve terminals (Griffiths 1980). Cadmium appears to also affect copper metabolism by displacing copper from sulfhydryl binding sites on metallothionein, which serves as the major copper-binding protein of the duodenum and liver (Evans et al. 1970), producing decreased plasma, liver and bone copper levels. Cadmium also appears to compete for iron binding sites in the intestinal mucosa, thus bringing about iron-deficiency anemia, white iron in turn produces amelioration of some effects of chronic cadmium 
toxicity (Bremner 1974). Finally, selenium, like zinc, has a protective effect against acute cadmium poisoning (Gunn et al. 1968).

One of the keys to the ultimate fate of cadmium in the body is metallothionein, a prote in of molecular weight 6,000 to 10,000 . Metallothione in appears to be important in zinc and copper storage and regulation. Binding of cadmium to metallothionein, however, forms an exceptionally stable complex and hence metallothionein combines with cadmium preferentially over these metals (Ochiai 1977). Synthesis of metallothione in by kidney, liver and spleen is induced by exposure to cadmium (Cherian and Goyer 1978; Suzuki et al. 1981) and cadmiumthione in complex is stably sequestered after resorption from the glomerular filtrate primarily in the kidney parenchyma (Nordberg 1978). This is thought to be a detoxification mechanism. When levers of cadmium in the cortex of the kidney reach $100 \mathrm{\mu g} / \mathrm{g}$, however, renal tubular dysfunction may occur, and irreversible renal failure is associated with accumulations of $200 \mu \mathrm{g} / \mathrm{g}$ (Friberg et a1. 1974; Cherian and Goyer 1978).

In light of the potential adverse health effects of cadmium, an understanding of the environmental sources of exposure to cadmium is important. The most obvious--and to date the most investigated-sources of cadmium exposure are industrial. In fact, nearly all cadmium exposure is essentially industrial, since cadmium concentrations characteristic of undisturbed nature are very low (except in the rare cadmium sulfide-based mineral greenockite) and relatively immobile, but mining, refining and manufacturing processes provide greatly improved opportunities for accumulation by animals and plants 
alike. Nevertheless, industrial settings offer potentially heavy exposure through welding, soldering, electroplating, pigmentmanufacturing, and other processes which may involve the use of cadmium (Hunter 1969). Exposure to air or water-borne cadmium produced as a by-product of the refining of metals, particularly zinc, may affect the general population as well as industrial workers.

The most obvious source of cadmium exposure which is not directly industrial is diet. For the most part measured levels of cadmium in food are quite low--below $0.05 \mu \mathrm{g} / \mathrm{g}$ (Friberg et al. 1974). Conspicuous exceptions are shellfish in general and oysters in particular (.1-7.8 $\mu \mathrm{g} / \mathrm{g}$; Pringle et al. 1968), anchovies and tea (5.39 and 1.38-2.50 $\mathrm{g} / \mathrm{g}$ respectively; Schroeder et al. 1967b).

Levels of cadmium reported in drinking water vary greatly. Although "unpolluted" water has cadmium concentrations of less than $1 \mu \mathrm{g} / \mathrm{L}$ (Friberg et al. 1974), the APHA (1976) reports concentrations ranging from 0.4 to $60 \mu \mathrm{g} / \mathrm{L}$ in U.S. drinking water. Altogether, from both indirect calculations and based on analys is of foodstuffs and average consumption (Duggan and Corneliussen 1972) and direct studies of fecal excretion (Tipton and Stewart 1970), it is estimated that total intake of cadmium in areas free of serious pollution will generally be in the range of 40-50 $\mu$ g/day in the U.S. The World Health Organization has provisionally established tolerable weekly intake of cadmium as 400-500 $\mu \mathrm{g}(57-71 \mu \mathrm{g} /$ day $)$ for a "standard $60 \mathrm{~kg}$ man" (Cheftel et al. 1972).

A less obvious non-industrial source of cadmium is tobacco smoking. A 1969 study of 6 brands of cigarettes found that an average 
pack of 20 cigarettes contained nearly $23 \mu \mathrm{g}$ of cadmium with only minor variation between brands (Nandi et a1. 1969). Menden et al. (1972) measured the cadmium concentrations in whole cigarettes and in mainstream smoke. They found that of 1.56 to $1.96 \mu \mathrm{g}$ of cadmium per whole cigarette, 0.10 to $0.12 \mu \mathrm{g}$ was in particulate form in the fraction of smoke normally inhaled. Based on this data it can be estimated that smoking one pack of cigarettes per day will contribute at least $2 \mu \mathrm{g}$ to daily cadmium intake. This is not a large contribution to average raw intake, but much higher retention is to be expected because the cadmium is inhaled rather than taken orally. The potential contribution to daily cadmium retention of tobacco smoking is thus quite substantial, being estimated at $1 \mu \mathrm{g} /$ day for a pack-a-day smoker versus $2.25 \mu \mathrm{g} /$ day average retention via food (Friberg et a1. 1974).

Studies confirming the potential contribution of tobacco smoking to retained cadmium and hence body burden have been conducted on cadavers and, on a small scale, in vivo. In an autopsy study Lewis et al. (1972) found a total burden of $14.2 \mathrm{mg}$ of cadmium for kidney, 1iver and lung combined in smokers and $6.8 \mathrm{mg}$ in nonsmokers. Ostergaard (1978) reported that renal cadmium concentrations in autopsied samples from cigarette smokers were nearly twice as high as in nonsmokers. Finally, Ellis et al. (1979) determined cadmium levels in the left kidney and liver of 20 male volunteers using partial body neutron activation and found tobacco smokers to have nearly double the levels of nonsmokers in both organs. 


\section{INTRODUCTION}

A more convenient analytical technique for cadmium other than autopsy or partial body neutron activation would be of obvious value in the investigation of aspects of cadmium metabolism, such as its relationship with smoking, for studies on living subjects. Blood analysis is a fairly common technique for investigating metals, but levels of cadmium in the blood are unfortunately low. The median normal concentration of cadmium is about $0.6 \mathrm{ng} / \mathrm{g}$ (Ediger and Coleman 1973) yet there can be enormous fluctuation. Values of less than .5 to $14.2 \mu \mathrm{g} / 100 \mathrm{ml}$ have been reported for whole blood in a single study (Kubota et a1. 1968), for example. This fluctuation may derive in part from cadmium's rapid turnover rate upon entering the bloodstream. For example, Shaikh and Lucis (1972b) reported that cadmium levels in the plasma of rats declined within 48 hours after subcutaneous administration of ${ }^{109} \mathrm{Cd}$ to the lower limit of detection. The other common technique for determining metal levels in vivo, urinalysis, also involves low sample concentrations: excretion of cadmium appears to be mainly via the intestinal tract (Shaikh and Lucis 1972a), which accounts for the relatively low urinary levels of cadmium, generally in the range of 1-2 $\mu \mathrm{g} / \mathrm{L}$ (Friberg et al. 1974). A less common analytical technique, however, potentially offers specimens with higher normal metal levels and lower concentration transience than either blood or urine analysis. This technique is hair analysis. 
Initial interest in analysis of hair for trace metals was primarily for forensic applications. However, Kopito et al. (1967) reported good correlation between hair lead content and clinical findings of lead poisoning in children, and recommended the use of hair analysis as a simple screening procedure. The use of hair analysis in medical and biological applications has since grown (Maugh 1978; Klevay 1978), while frustration over the inability to control for intra-individual variations in the distribution of elements has dulled interest in forensic applications to the point that one worker was moved to subtitle a report evaluating the forensic analysis of hair the "Failure of a mission" (Cornelius 1973).

Hair is a cystine-rich keratinized tissue. The disulfide bonds formed between cystine residues of the helically-coiled polypeptide chains which make up the keratin molecule give it most of its stability (Baden et a1. 1973; Hopps 1977). Sulfur groups in general and cystine's in particular are also preferred binding sites for "heavy" trace metals like cadmium (Ochiai 1977); thus the same chemical characteristics which stabilize the keratin of hair result in its having high concentrations of many metals. Another valuable characteristic of hair is that it provides a relatively nonperishable specimen. And, as a constantly forming tissue, it potentially acts as a continual monitor of metal levels over time. A lock of hair thus avoids the transience problems associated with blood or urine specimens, for example, by providing an average reading of levels over a long time period. 
The question of the extent to which metal levels in hair reflect actual body metal burdens is debated (e.g. Prasad et a1. 1963;01eru 1975; Maugh 1978; Chittleborough 1980). A fundamental problem is determining just what "body burden" indicators should be compared to hair metal concentrations since concentrations found in the body normally vary from tissue to tissue and hair may be considered a tissue itself. Numerous studies have demonstrated associations between increased or decreased intake, or tissue levels in general, and hair levels, from which many investigators have concluded, as did Hopps (1977), that hair is suitable for evaluating body stores.

Schroeder and Nason (1969) apparently published the first survey of cadmium concentrations in human hair. In a study of 117 males and 47 females using atomic absorption spectrophotometry they found average levels of $2.76 \mu \mathrm{g} / \mathrm{g}$ for men and $1.77 \mu \mathrm{g} / \mathrm{g}$ for women, with lower levels of cadmium for older than for younger women. They also studied zinc, and found essentially identical average levels of 167 and $172 \mu \mathrm{g} / \mathrm{g}$ for men and women, respectively, with no significant difference with age. Another 1969 study, using spark source mass spectrometry (Yurachek et a1.), found cadmium concentrations in hair ranging from 0.34 to $1.8 \mu \mathrm{g} / \mathrm{g}$ but apparently involved only a few subjects; values of 143 to $246 \mu \mathrm{g} / \mathrm{g}$ were found for zinc. Values of cadmium and zinc levels published in these and subsequent studies are summarized in Appendix A.

Studies of hair cadmium directed to more specific purposes followed these initial works. Mean hair levels of cadmium, as well as lead, accurately reflected community exposure in investigations by 
Hammer et a1. (1971), results which were mirrored by investigations of cadmium, mercury and lead by Chattopadhyay et a1. (1977). Zinc levels did not reflect exposure and this was attributed to relatively small differences in total zinc exposure between groups, due in part to the large normal dietary zinc component, and the possession of more effective homeostatic mechanisms for zinc than for cadmium. Eads and Lambdin (1973) report a decline in cadmium and zinc in the hair of females in the age range from 32 to 72 years and higher zinc levels in darker colored hair for both sexes which, they concluded, implicated zinc in the production of melanin involved in hair pigmentation. 0leru (1976) compared cadmium levels in kidney, liver, hair and lungs for 50 autopsied New Yorkers and found significant positive correlations between al1 4 tissues, with a particularly strong correlation between kidney and hair (0.52). Oleru also reported a general increase in hair and kidney cadmium levels with age. Finally, in experimental studies on laboratory animals, Kollmer and Berg (1979) found the amount of cadmium detected in hair as well as total body, various tissues, and blood samples to be proportional to doses of cadmium administered intravenously.

Hair studies of only zinc had preceded those including only cadmium or both elements. Bate and Dyer (1965), Perkons and Jervis (1966), and Harrison et al. (1969) surveyed hair for zinc and other metals. In 1966 Strain et al. found good correlations between low zinc levels in hair and zinc deficiency syndromes. Petering et al. (1971b) found a close relationship between decreasing hair zinc concentration and age for males over 15 and for females, with no significant 
difference in levels between the sexes. A study by Obrusnik et al. (1973) revealed a slight decrease in concentration of zinc with distance from the scalp, contrasting with a previous study (1972) by the same group which had found no such decrease, but another study (Rendic et a1. 1976) found zinc concentrations essentially constant along the length of hair from 0 to $30 \mathrm{cms}$ distal. Experimental studies by Deeming and Weber (1977) found good correlations between dietary zinc intake and hair zinc levels in rats. Finally, McKenzie (1979) reported no significant differences between hair zinc levels in oyster openers or industrial workers and unexposed individuals with the exception of galvanizers, but there was a significant difference between levels in the sexes $(195 \mu \mathrm{g} / \mathrm{g}$ for females vs $180 \mu \mathrm{g} / \mathrm{g}$ for males).

Despite the discovery of substantial amounts of cadmium in tobacco and its potential contribution to cadmium exposure when smoked, no previous studies have examined the possible contribution of marijuana smoking to cadmium exposure. Nor were there any studies exploring the relationship between cadmium and zinc levels in human smokers and nonsmokers or even the impact of smoking on hair metal levels in evidence in the literature. Thus, this study investigates the relationship of cadmium and zinc levels in hair to smoking habits, including both tobacco and marijuana use. 


\section{MATERIALS AND METHODS}

The research project entailed two separate studies, an initial small scale pilot study being carried out six months prior to the ma in study. Particulars in which the pilot study differed from the ma in study are indicated following the general descriptions.

\section{Subjects and Sample Collection}

Volunteer subjects were recruited from students enrolled in biology courses at Portland State University. The volunteers completed an informed consent form and a separate anonymous questionnaire (identified only by a code number) covering tobacco and marijuana smoking habits, and a variety of other factors which potentially affect hair trace metal levels. The questionnaire is reprinted in Appendix $B$.

Hair samples were taken from the occipital region of the scalp within 24 hours after the hair had last been washed and were stored in clean plastic bags. Only the portion of the hair strand within $6 \mathrm{~cm}$ of the scalp was used in the subsequent analysis.

In the pilot study no restriction was placed on the distance of analyzed hair sections from the scalp.

\section{Laboratory Reagents and Cleansing Protocol}

All chemicals used were of A.C.S. reagent grade. All distilled water used was deionized by passage through an ion exchange column. Stock standards for atomic absorption spectroscopy were prepared in the lab by dissolving cadmium (Cd) and zinc $(\mathrm{Zn})$ metal in acid; fresh 
working standards were made prior to spectroscopic analysis of samples. Standards were made in $0.4 \mathrm{M} \mathrm{HNO}_{3}$ to minimize loss of cadmium from solution through adsorption onto the container walls.

Al1 glassware (pyrex) used in sample pretreatment and digestion and plasticware ( 7 inear polyethylene) used in sample storage was subjected to a stringent cleansing procedure entailing four major steps, each step followed by rinsing with deionized distilled water.

These steps consisted of: 1) Washing and scrubbing with hot tap water; 2) Soaking at least 12 hours in nonionic detergent solution prepared with distilled water; 3) Soaking in $2 \mathrm{M} \mathrm{HCl}$; and 4) Letting stand for 2 hours filled with $3 \mathrm{M} \mathrm{HNO}_{3}$.

\section{Sample Pre-treatment}

Samples of 0.2 to 0.6 gram of hair were placed in $50 \mathrm{ml}$ beakers in which they were rinsed twice with distilled water and then, after addition of about $35 \mathrm{ml}$ of distilled water, placed on a mechanical agitator for 40 minutes. Following agitation the washwater was poured off and the samples rinsed three times with distilled water and placed in a drying oven at $110^{\circ} \mathrm{C}$ overnight. Samples were stored in a desiccator after drying until ready for use. Duplicates were prepared for hair samples of one gram or more.

In the pilot study a 30 minute nonionic detergent wash was used instead of the 40 minute water wash.

Sample Digestion and Analys is

Washed, dried hair samples of from 0.2 to $0.6 \mathrm{~g}$ were weighed to $\pm 1 / 10 \mathrm{mg}$ into $25 \mathrm{ml}$ Erlenmeyer flasks. After addition of $6 \mathrm{ml}$ 
$5: 1 \mathrm{HNO}_{3}: \mathrm{H}_{2} \mathrm{O}$ samples were covered with watchglasses and allowed to sit overnight. The flasks were then placed on hot plates where after 50 minutes of gentle heating they were cooled for 10 minutes, the watchglasses were removed, $4 \mathrm{ml}$ of conc. $\mathrm{HNO}_{3}$ was added, and heating was continued for about 3 hours. At this point the samples were allowed to cool for 15 minutes, $2 \mathrm{ml}$ of $1: 2 \mathrm{HClO}_{4}: \mathrm{HNO}_{3}$ was added and gradual heating to a gentle boil (c. $110^{\circ} \mathrm{C}$ ) continued for another hour and 40 minutes, when they were again allowed to cool for 15 minutes and then transferred to $10 \mathrm{ml}$ beakers. The samples were then heated until a clear solution was obtained and just enough solution remained to cover the bottom of the beakers, $\mathrm{HNO}_{3}$ being added dropwise whenever a solution darkened, and then allowed to cool. When cool, samples were transferred to $5 \mathrm{ml}$ volumetric flasks and $1: 20 \mathrm{HNO}_{3}: \mathrm{H}_{2} \mathrm{O}$ was added to bring the solutions to $5 \mathrm{ml}$. These solutions were then stored in $5 \mathrm{ml}$ polyethylene bottles prior to analysis.

Reagent blanks were treated with the same procedure for each batch of hair samples.

Digested hair sample solutions and standards were analyzed for Cd by direct aspiration into an IL 551 atomic absorption spectrophotometer in flame mode under standard conditions (as per IL 551 Operator's Manual). Replicate determinations of $\mathrm{Cd}$ were made for each sample, and the order in which the samples were analyzed was reversed for the second determination. Accurate determination of $\mathrm{Zn}$ required dilution of the original sample solution. Thus, remaining volume permitting, samples were then diluted ten-fold by pipetting $1.00 \mathrm{ml}$ of sample into a $10 \mathrm{ml}$ volumetric flask, diluting to volume with 
deionized water and transferring the diluted solution to a $20 \mathrm{~m} 1$ polyethylene bottle. These solutions were then analyzed for $\mathrm{Zn}$ using the same general methodology as for Cd.

In the pilot study hair samples were weighed out onto weighing paper which was then folded into packets and samples were gradually added to the digestion medium as digestion proceeded. $\mathrm{No}_{\mathrm{HClO}}$ was used in the pilot study, nor was the initial digestion carried out in a $25 \mathrm{ml}$ Erlenmeyer. Instead all digestion was carried out in $10 \mathrm{~m} 7$ beakers, using $\mathrm{HNO}_{3}$ exclusively. 


\section{RESULTS}

The pilot study included a total of 37 subjects, all of whom were tested for hair cadmium. Table I summarizes the data obtained for cadmium levels in the hair of the group as a whole and of subdivisions based on sex and smoking habits. The main study included a further 97 subjects, all of whom were tested for cadmium and 72 of whom were tested for zinc. On the average, $40-45 \%$ of the individuals in classes recruited volunteered in the main study. Concentrations ranged from 0.28 to $3.58 \mathrm{\mu g} / \mathrm{g}$ for cadmium and from 99 to $300 \mu \mathrm{g} / \mathrm{g}$ for zinc. Tables II and III summarize the data obtained for cadmium and zinc, respectively. Individual values for cadmium and zinc by smoking habits and sex are presented in Appendices $C$ and $D$.

In both studies the average cadmium level in the hair of current tobacco smokers $(1.35$ and $0.97 \mathrm{\mu g} / \mathrm{g}$ for the pilot and main study, respectively) exceeded that of nonsmokers $(0.69$ and $0.71 \mu \mathrm{g} / \mathrm{g}$ for pilot and main study). This difference was statistically significant in both studies $(P=.031$ for ma in and .048 for pilot study). Since Bartlett's Test for homogeneity of variance indicated that the cadmium data summarized in Tables I and II deviated significantly from homogeneity unless it was logarithmically transformed, an additional ANOVA was performed on log transformed data. This analysis, too, yielded statistically significant results for the main study $(P=.036)$, but results for the pilot study exceeded the limit of statistical significance after transformation $(P=.080)$. In addition, the average 


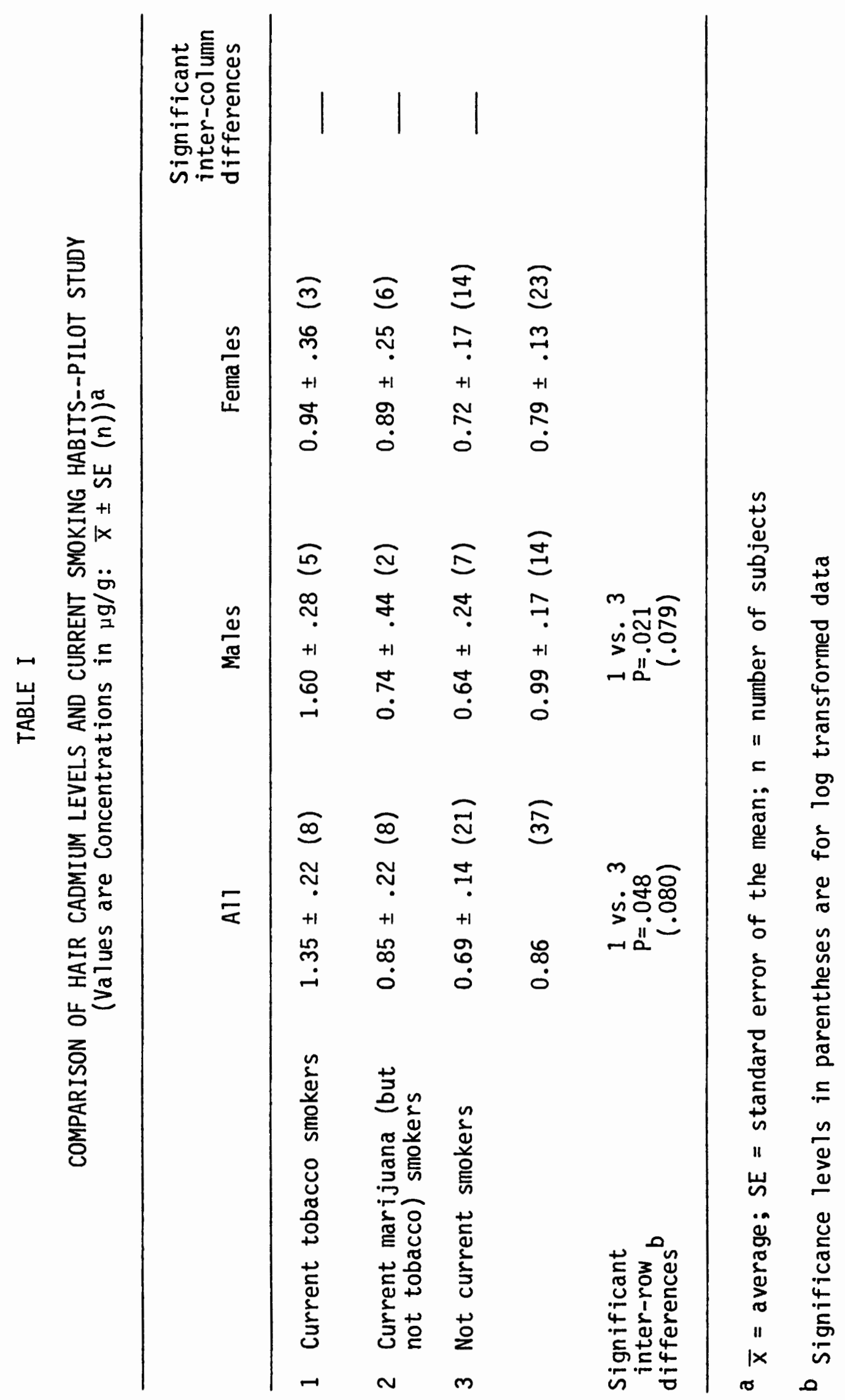




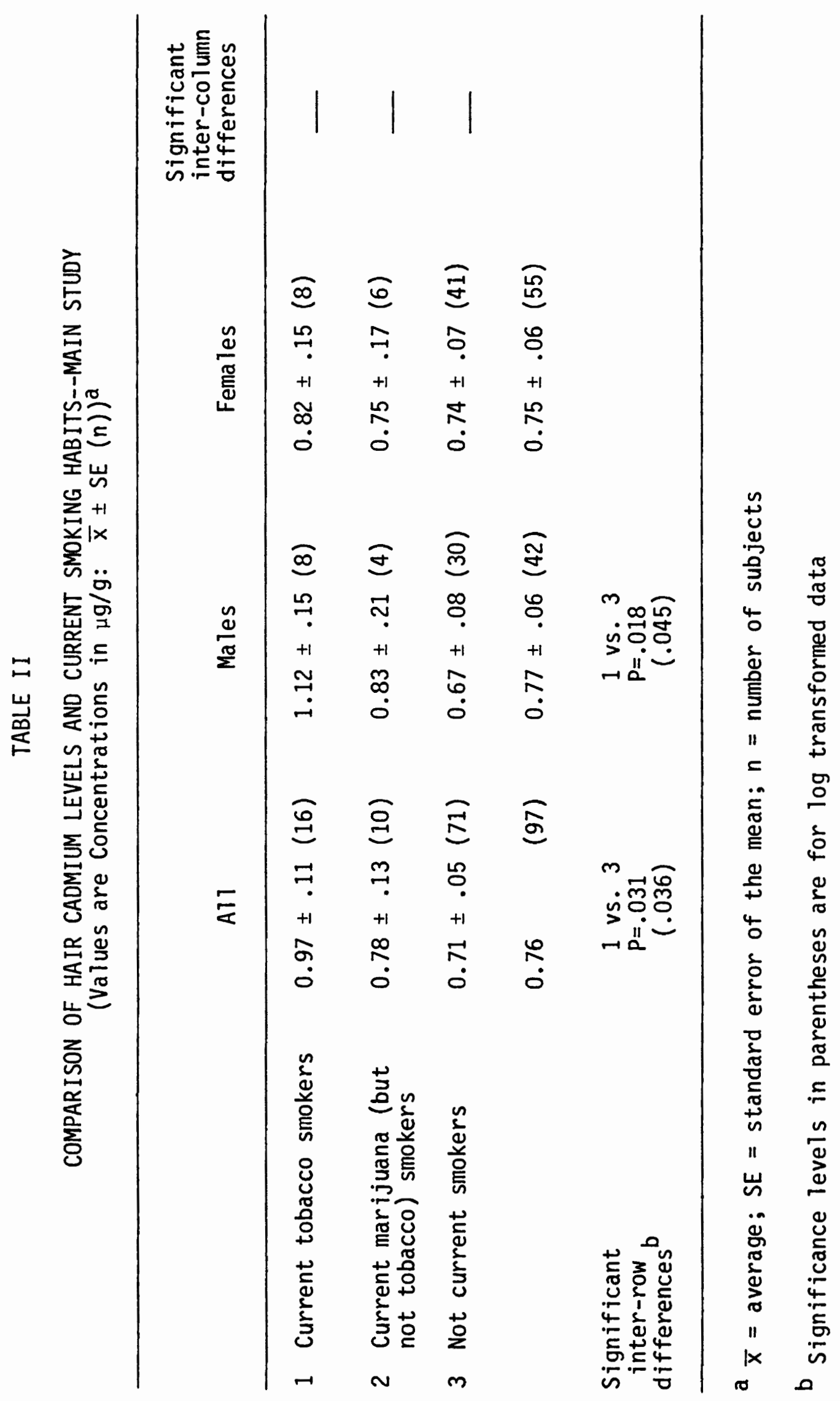




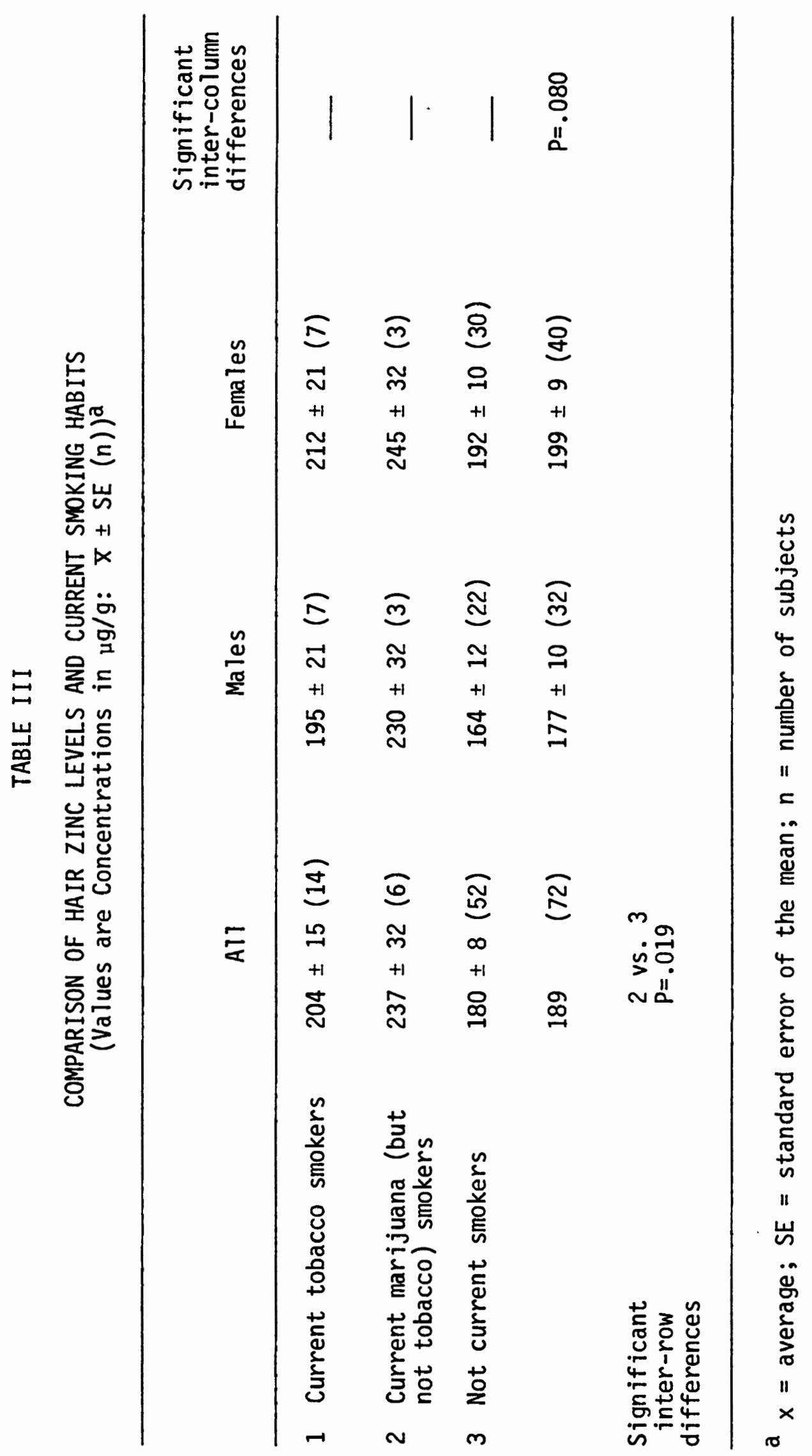


cadmium level observed for current marijuana smokers who were not also current tobacco smokers $(0.79$ and $0.78 \mu \mathrm{g} / \mathrm{g}$ for pilot and ma in study, respectively) exceeded that of nonsmokers but not significantly so. These relationships held for the group as a whole and for each sex individually. (Tables I and II)

Average hair zinc levels for current tobacco smokers $(204 \mu \mathrm{g} / \mathrm{g})$ also exceeded those for nonsmokers $(180 \mu \mathrm{g} / \mathrm{g})$ but not significantly so. However, average zinc levels for current marijuana-but-nottobacco smokers $(237 \mu \mathrm{g} / \mathrm{g})$ did significantly exceed $(P=.019)$ those for nonsmokers and were also observed to exceed those for current tobacco smokers. This relationship, too, held for the group as a whole and for both sexes individually. (Table III)

In the pilot study, average cadmium levels for males exceeded those for females but average levels for nonsmoking males were lower than those for nonsmoking females; neither difference was, however, significant. In the main study observed average cadmium levels for males were essentially the same as those for females for both smokers and nonsmokers. Zinc levels, on the other hand, appeared higher for females than for males regardless of smoking habits (199 vs. $177 \mu \mathrm{g} / \mathrm{g}$, $\mathrm{P}=.080)$. (Table III)

An alternative analysis of the data on smoking habits and hair cadmium concentration is summarized in Table IV. The average hair Cd level observed for heavy (tobacco) smokers $(1.06 \mu \mathrm{g} / \mathrm{g}$ ) exceeded that for nonsmokers $(P=.014)$, as did the average level for 1 ight (tobacco and/or marijuana) smokers $(0.79 \mu \mathrm{g} / \mathrm{g} ; \mathrm{P}=.430)$. In addition, 


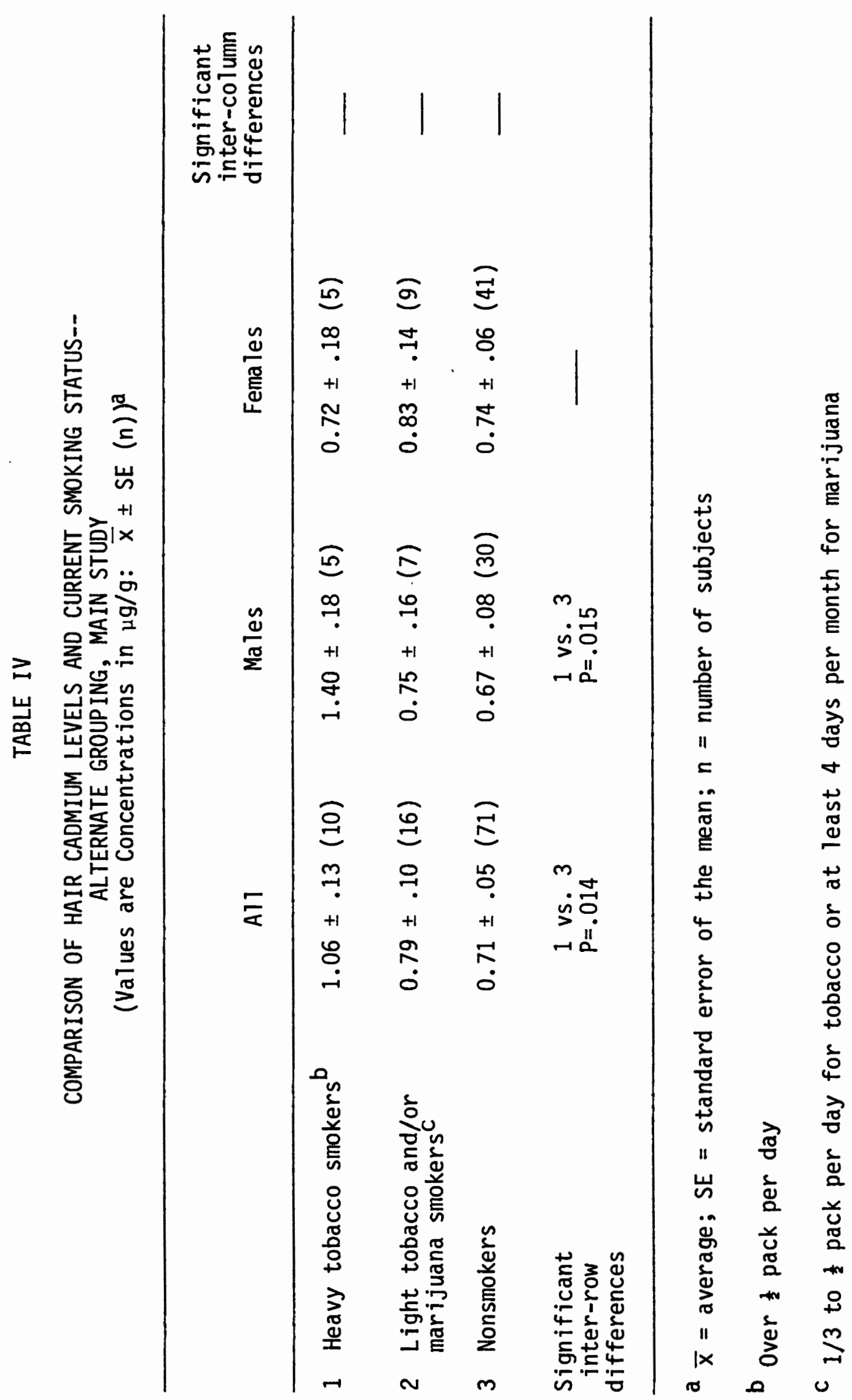


the average Cd Tevel observed for heavy smokers exceeded that for light smokers $(P=.110)$.

A comparison of current and former tobacco smokers is presented in Table $V$. Both average hair cadmium and average hair zinc were lower but not significantly so for former tobacco smokers $(0.61$ and $161 \mu \mathrm{g} / \mathrm{g})$ than for current tobacco smokers or for nonsmokers $(0.73$ and $183 \mu \mathrm{g} / \mathrm{g})$.

The results for relationship between age and hair cadmium are summarized in Table VI and Figure 1. Cadmium concentration tended to increase with age, although for females the relationship was relatively inconsistent and broke down after age 30. Zinc concentration showed no discernible correlation with age (see Table VI).

The relationship between body weight and hair cadmium concentration was also examined but no apparent correlation was found. Figure 2 summarizes these data.

Possible correlation of hair color, soldering, recent flu and oral contraceptive use with hair metal levels was examined using the cadmium and zinc measurements and the questionnaire responses. The results are summarized in Table VII. Black hair had a marginally significant elevation in zinc level $(P=.050)$. Observed but not statistically significant associations were noted between black hair, recent flu, and oral contraceptive use and lower than average Cd levels whereas soldering was associated with higher than average levels; recent flu and oral contraceptive use were also associated with lower than average zinc levels. 
TABLE V

COMPARISON OF HAIR CADMIUM AND ZINC LEVELS FOR CURRENT, FORMER AND NON-SMOKERS

(Values are Concentrations in $\mu \mathrm{g} / \mathrm{g}: \overline{\mathrm{x}} \pm \mathrm{SE}(\mathrm{n}))^{2}$

\begin{tabular}{|c|c|c|c|}
\hline & All & Mates & Females \\
\hline \multicolumn{4}{|c|}{$\mathrm{Cd}$} \\
\hline 1 Current tobacco smokers & $0.97 \pm .11(16)$ & $1.12 \pm .16(8)$ & $0.82 \pm .16(8)$ \\
\hline 2 Former tobacco smokers & $0.61 \pm .13(11)$ & $0.53 \pm .18(6)$ & $0.70 \pm .20(5)$ \\
\hline \multirow[t]{2}{*}{$\begin{array}{l}3 \text { Not current tobacco or } \\
\text { marijuana smokers }\end{array}$} & $0.73 \pm .06(60)$ & $0.71 \pm .09(24)$ & $0.74 \pm .07(36)$ \\
\hline & 0.76 & $0.77 \pm .07(38)$ & $0.75 \pm .06(49)$ \\
\hline \multirow[t]{2}{*}{$\begin{array}{l}\text { Significant } \\
\text { inter-row } \\
\text { differences }\end{array}$} & $\begin{array}{l}1 \text { vs. } 2 \\
P=.042 \\
1 \text { vs. } 3 \\
P=.059\end{array}$ & & \\
\hline & \multicolumn{2}{|c|}{$\mathrm{Zn}$} & \\
\hline 1 Current tobacco smokers & $204 \pm 14(14)$ & $195 \pm 20(7)$ & $212 \pm 20(7)$ \\
\hline 2 Former tobacco smokers & $161 \pm 20(7)$ & $158 \pm 27(4)$ & $166 \pm 31(3)$ \\
\hline \multirow{2}{*}{$\begin{array}{l}3 \text { Not current tobacco or } \\
\text { marijuana smokers }\end{array}$} & $183 \pm 8(45)$ & $165 \pm 13(18)$ & $194 \pm 10(27)$ \\
\hline & $185 \quad(66)$ & $171 \pm 10(29)$ & $195 \pm 9(37)$ \\
\hline $\begin{array}{l}\text { Significant } \\
\text { inter-row } \\
\text { differences }\end{array}$ & $\begin{array}{l}1 \text { vs. } 2 \\
p=.09\end{array}$ & & \\
\hline
\end{tabular}

${ }^{a} \bar{X}=$ average $; S E=$ standard error of the mean; $n=$ number of subjects 
TABLE VI

CADMIUM AND ZINC CONCENTRATIONS $(\mu g / g)$ VS. AGE (years)

\begin{tabular}{|c|c|c|c|c|c|c|}
\hline \multirow[b]{2}{*}{ Age } & \multirow{2}{*}{$\begin{array}{c}\text { All } \\
\text { Males }\end{array}$} & \multirow{2}{*}{$\begin{array}{l}\text { All } \\
\text { Females }\end{array}$} & \multicolumn{2}{|c|}{ Males } & \multicolumn{2}{|c|}{ Females } \\
\hline & & & Tob. Smok. & Non Smok. & Tob. Smok. & Non Smok. \\
\hline \multicolumn{7}{|c|}{ Cd } \\
\hline $17-20$ & $0.66(6)^{a}$ & $0.73(13)$ & $1.52(1)$ & $0.49(5)$ & $1.38(1)$ & $0.68(12)$ \\
\hline $21-25$ & $0.68(15)$ & $.71(18)$ & $.69(4)$ & $.68(11)$ & $.75(4)$ & $.70(14)$ \\
\hline $26-30$ & $.74(9)$ & $.83(14)$ & - & $.74(9)$ & $.65(3)$ & $.88(11)$ \\
\hline $31-39$ & $.79(5)$ & $.61(6)$ & $.52(1)$ & $.85(4)$ & $.33(1)$ & $.67(5)$ \\
\hline $40-49$ & $.99(1)$ & - & - & $.99(1)$ & - & - \\
\hline $50+$ & - & $1.02(2)$ & - & - & $.80(1)$ & $1.25(1)$ \\
\hline \multicolumn{7}{|c|}{$\mathrm{Zn}$} \\
\hline $17-20$ & $217(5)$ & $193(11)$ & $300(1)$ & $197(4)$ & $242(1)$ & $188(10)$ \\
\hline $21-25$ & $182(11)$ & $209(11)$ & $161(4)$ & $194(7)$ & $215(3)$ & $207(8)$ \\
\hline $26-30$ & $158(7)$ & $199(11)$ & - & $158(7)$ & $230(3)$ & $188(8)$ \\
\hline $31-39$ & $173(4)$ & $188(3)$ & $184(1)$ & $169(3)$ & $115(1)$ & $224(2)$ \\
\hline $40-49$ & $166(1)$ & - & - & $166(1)$ & - & - \\
\hline $50+$ & - & $234(2)$ & - & - & $279(1)$ & $190(1)$ \\
\hline
\end{tabular}

a Numbers in parentheses are $n$ values for corresponding concentrations 


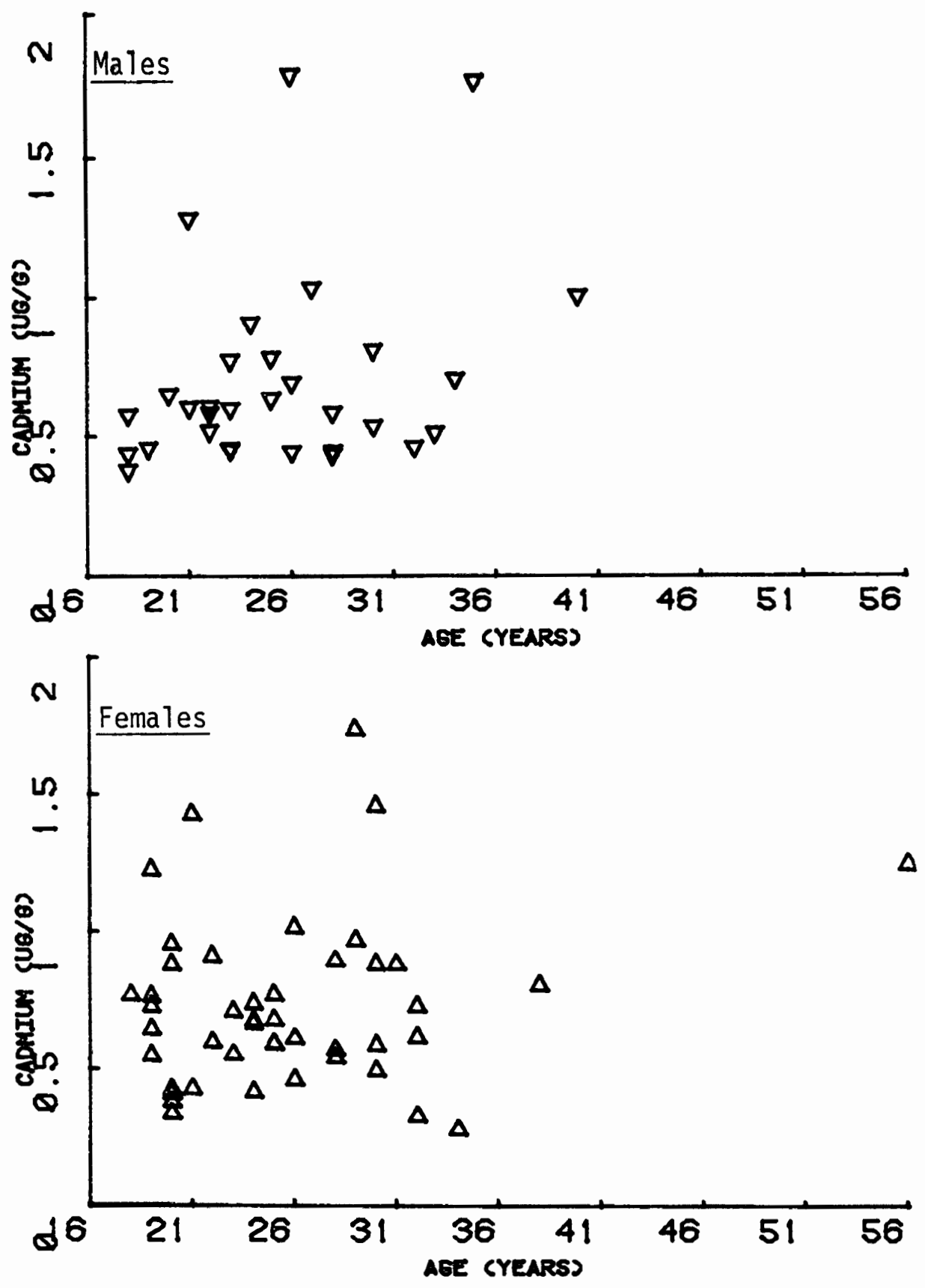

Figure 1. Cadmium concentration in hair $(\mu \mathrm{g} / \mathrm{g})$ as a function of age (years) for male and female nonsmokers. 


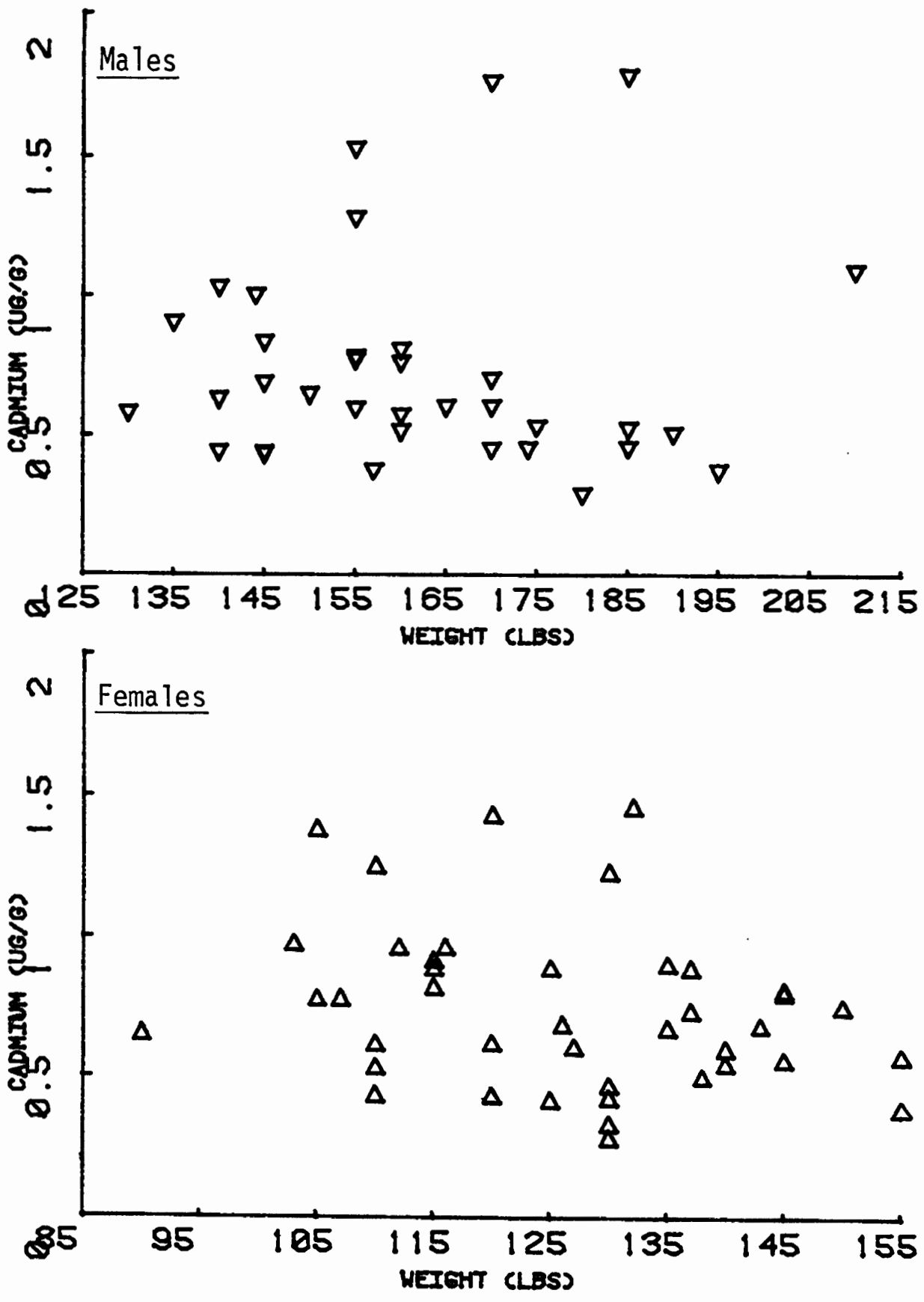

Figure 2. Cadmium concentration in hair $(\mu \mathrm{g} / \mathrm{g})$ as a function of body weight (lbs) for male and female nonsmokers. 


\section{TABLE VII}

DIFFERENCES IN AVERAGE HAIR CADMIUM AND ZINC LEVELS $(\mu \mathrm{g} / \mathrm{g})$ ASSOCIATED WITH MISCELLANEOUS FACTORS

Factor

Subjects

$\bar{X} \mathrm{Cd}$

(n) $\quad \bar{x} Z n$

Black hair

7 black-haired

male smokers

$.542 \pm .15$

(4) $200 \pm 19$

17 male nonsmokers

$.777 \pm .09$

(14) $155 \pm 10$

$\mathrm{P}=.20(.18)^{\mathrm{a}}$

$P=.05$

Soldering

5 solderers

$$
.833 \pm .19
$$

92 non-solderers

$$
\begin{aligned}
& .744 \pm .05 \\
& P=.65(.52)
\end{aligned}
$$

(Only $2 \mathrm{Zn}$ values were obtained for solderers)

Note: solderers include 2 individuals with black hair and 1 with recent flu.

Oral

contraceptives
6 oral. contra.

users

35 nonusers

$$
\begin{aligned}
& .578 \pm .13 \\
& .763 \pm .05 \\
& P=.20(27)
\end{aligned}
$$

(5) $163 \pm 26$

(25) $197 \pm 12$

$P=.23$

Note: all users/nonusers compared for $\mathrm{Zn}$ are non smokers

Recent

flu
$3 \mathrm{males} w / \mathrm{rec}$. flu $\quad .465 \pm .32$

39 males w/o rec. flu $.795 \pm .09$

$$
P=.33(.17)
$$

(3) $\quad 139 \pm 28$

(29) $181 \pm 9$

$P=.18$

Note: Males w/recent flu include 1 solderer, 1 with black hair, and 1 curr. tob. and mar. smoker 


\section{DISCUSSION}

The results of this study indicate that current tobacco smoking is associated with elevated hair cadmium levels compared to nonsmoking (ANOVA, $P=.031$ ). This observed elevation in hair cadmium levels is consistent with the observation of higher cadmium body burdens for tobacco smokers after autopsy (Lewis et a1. 1972; Ostergaard 1978) and in vivo (Ellis et al. 1979) studies of cadmium 1oad, and with the significant cadmium content of tobacco $(1.56-1.96 \mu \mathrm{g} / \mathrm{cigarette}$; Menden et al. 1972). These data support the hypothesis that intake of cadmium through tobacco smoking is reflected by higher cadmium levels in hair as well as higher total body cadmium burden.

A1 though elevation of mean hair cadmium concentration in current marijuana smokers was observed in both the main and pilot studies and for both sexes, the relationship was not statistically significant. Thus, al though the data is consistent with the hypothesis that marijuana smoking, too, contributes to cadmium exposure, the results are inconclusive.

The observation of a smaller elevation of concentrations of cadmium in the hair of marijuana smokers than of tobacco smokers relative to nonsmokers is, however, consistent with the idea that a smoker's average total consumption of marijuana is likely to be much lower than that of tobacco. This is prompted by differences in styles of usage, price, ease of obtainment and frequency of circumstances where use is unacceptable (due to legal and/or social 
pressures), all of which would presumably favor consumption of lower quantities of marijuana than tobacco. This idea is borne out by the observation of higher average hair cadmium concentrations in current heavy tobacco smokers $(1.06 \mu \mathrm{g} / \mathrm{g})$ than in marijuana-light tobacco smokers pooled $(0.79 \mu \mathrm{g} / \mathrm{g})$, while the average for this pooled group is essentially the same as that for current regular marijuana-butnot-tobacco smokers alone $(0.78 \mu \mathrm{g} / \mathrm{g})$, and is also higher than that for nonsmokers $(0.71 \mu \mathrm{g} / \mathrm{g})$ but not significantly so. (Table IV)

The average hair cadmium values obtained in this study are lower than those obtained by Schroeder (1969), Eads and Lambdin (1973), Petering et a1. (1973), and Chattopadhyay et a1. (1977) for urban adults. The subjects of the present study were, however, relatively young (average age under 26 years) and included a relatively small proportion of smokers, both factors which, as previous and ensuing discussion indicates, lower average cadmium concentrations should be associated with. This study's values are in general agreement with the work of Yurachek et al. (1969), and the values of Chattopadhyay et a1. (1977) for adults in nonindustrial settings. (Appendix A)

The elevation of hair zinc levels in tobacco smokers was initially somewhat surprising. The competition for binding sites on proteins that is associated with the metabolic antagonism of cadmium and zinc suggested that zinc levels and overall zinc-cadmium ratios might be lower in smokers. However, zinc normally was present in hair at concentrations approximately 200-fold that of cadmium. Thus, indications of any simple displacement or replacement phenomenon 
of zinc by cadmium would be obscured by variation in zinc levels. Furthermore, it is known that cadmium and zinc tend to be found in close association in nature and that zinc is an essential nutrient for plants in general (Epste in 1972; Gauch 1972) and tobacco in particular (Hoagland et al. 1936), so it would not be surprising if tobacco contained substantial amounts of zinc as well as containing cadmium. The results, then, indicate that tobacco smoking may be a source of exposure to zinc as well as cadmium, but aga in lack sufficient statistical significance $(P=.16)$ to be conclusive.

On the other hand, the results for zinc levels in current marijuana smokers and nonsmokers are statistically significant $(P=.019)$ in their indication of an association between marijuana smoking and elevated hair zinc levels. The explanation for this result may be generally the same as that cited in the case of tobacco smokers. Metabolic alteration by some inhaled component of the smoking material is another possibility, but there are no data pertaining to trace metal constituents of marijuana smoke and its effects on metal metabolism.

The overall results of this study also reflect upon the usefulness of hair analysis as an indicator of body metal burden. If tobacco smoking does serve as a source of cadmium, as previous studies and the elevation of hair cadmium associated with current tobacco smoking habits observed in this study suggest, and if hair metal levels do reflect body metal burden, then former tobacco smokers as well as current smokers should show higher hair cadmium concentrations than nonsmokers. In fact, former smokers do not show a higher average 
hair cadmium concentration than nonsmokers. (Only two of the twelve former heavy tobacco smokers showed levels above the average for nonsmokers.) This suggests that hair cadmium levels reflect recent exposure rather than total body burden.

Average cadmium (and zinc) levels observed for former heavy tobacco smokers are actually lower than those observed for nonsmokers, but are not significantly different statistically $(P=.43$ for males and .48 for females for $\mathrm{Cd} ., .52$ and .21 for $\mathrm{Zn}$ ). The possibility of an increase in metallothione in activity in response to cadmium exposure via tobacco smoking which carries over after smoking ceases, resulting in more effective sequestration of cadmium in internal organs at the expense of hair, is an interesting but purely speculative interpretation of these observations.

Since zinc is an essential metal for humans and has effective homeostatic regulation (Underwood 1971), body burden of zinc is not expected to increase significantly unless intake is substantially elevated. Thus the appearance of elevated zinc levels in the hair of tobacco smokers appears anomalous unless the hair is viewed as serving in the role of an excretory pathway to some extent. This suggests that in the case of zinc, too, hair may reflect exposure (an increase in which, results in increased excretion) rather than body burden.

Average cadmium levels were higher for all males than for all females in the pilot study but were essentialiy the same for all individuals of both sexes in the main study. Although this at first appears inconsistent, it is notable that in the pilot study the 
fraction of males and females who were current tobacco smokers was $5 / 14$ and $3 / 23$, respectively, whereas in the ma in study the fraction was $8 / 42$ and $8 / 55$. Thus the proportion of male current tobacco smokers decreased by almost half between the two studies while the proportion of female current tobacco smokers remained virtualiy unchanged. Also notable is the fact that observed average levels for male nonsmokers were actually lower--though not statistically so--than those for female nonsmokers in both studies. The results of this study regarding difference in hair cadmium between the sexes are more in agreement with Petering et al. (1973) than the classical results compiled by Schroeder and Nason (1969) or those reported by Eads and Lambdin (1973). Part of the discrepancy may arise from the smoking variable, e.g. the proportion of the generat U.S. population who smoke is around 40\% for ages 15-50 (DHEW 1979) while the proportion of this project's main study population who smoked was under $20 \%$. In addition, Schroeder and Nason's and/or Eads and Lambdin's study population may have contained an abnormally high proportion of male smokers--and in any case more U.S. males smoked relative to females at the time of the Schroeder study.

Hair zinc levels were lower for males than for females. This may indicate a characteristic sex difference, for although not statistically significant $(P=.080)$ the average levels of $177 \mu \mathrm{g} / \mathrm{g}$ and $199 \mu \mathrm{g} / \mathrm{g}$ for males and females, respectively, are in excellent agreement with the work of McKenzie (1979), who found mean concentrations of 180 for males and 195 for females in a group of New Zealand students ranging from 18 to 27 years of age. Klevay (1970) a1so found 
significantly higher hair levels in females than males, and it is notable that the 4 other studies which have compared concentrations for both sexes, while reporting no significant difference between the sexes, all observed higher average concentrations in females than in males (Reinhold et al. 1966; Schroeder and Nason 1969; Petering et a1. 1971b; Eads and Lambdin 1973; also see Appendix A).

The trend toward increasing cadmium with increasing age is also in general agreement with previous studies such as Eads and Lambdin's (1973) and 0leru's (1976). For the women, however, the not-verymarked increase in the under 30 year age range and the irregularity of results for the post-30 year range contradicts Petering et al.'s 1973 study's findings of a steady increase up to a peak between ages 40 and 50 and, for the men, the general increase with age also contradicts that study's findings of a levelling off around age 20 . The larger sample size of the Petering study (95 males and 83 females) and its much broader age distribution caution against acceptance of this project's indications regarding age and male hair cadmium levels.

Although it seemed probable that a general increase in food intake would also serve to increase cadmium intake and thereby increase hair levels, the lack of apparent correlation between weight and hair cadmium level does not support this hypothesis. Perhaps a more direct estimate of food intake such as daily calorie intake or body fat test would be more successful in this regard.

Finally, the findings for the influence of miscellaneous factors on hair metal level, although in most cases involving too few samples to be of statistical significance, are nonetheless worthy of comment. 
The lower average cadmium concentration for black haired males is in agreement with previous findings (Schroeder and Nason 1969); the exact cause for this relationship is unknown but apparently involves a difference(s) in structural makeup related to hair pigmentation. The significantly higher zinc concentration for black haired males is 1 ikewise in agreement with previous findings (Eads and Lambdin 1973). The higher cadmium among individuals who solder is consistent with the high cadmium content of most solder (Fasset and Irish 1978) and the observation of elevated blood and urine cadmium concentrations in solderers (Welinder et a1. 1977). No previous studies dealing with the effect of oral contraceptive use or recent flu on hair cadmium and zinc are known. Thus the finding that both seem to depress hair cadmium and zinc levels cannot be compared to any previous findings and must await verification before being considered significant. Still, oral contraceptives are known to alter trace metal metabolism, including lowering serum and plasma zinc concentrations (Smith and Brown 1976). And it is not unreasonable that a bout of flu might put a heavy demand on zinc since zinc is involved in the immune system, thus resulting in a decrease of zinc levels in hair formed during the course of $i l l n e s s$, although this does not explain the concurrent depression in cadmium level. 


\section{LITERATURE CITED}

American Public Health Association. 1976. Standard methods for the examination of water and wastewater. 14th ed. American Public Health Association, Washington, D.C. 1193pp.

Baden, H.P., L. Goldsmith and B. Fleming. 1973. A comparative study of the physicochemical properties of human keratinized tissues. Biochim. et Biophys. Acta 322: 269-278.

Bate, L.C. and F. Dyer. 1965. Trace elements in human hair. Nucleon ics 23: 74-80.

Bierenbaum, M., et a1. 1975. Possible toxic factor in coronary heartdisease. Lancet 1: 1008-1010.

Bonne11, J.A. 1955. Emphysema and proteinuria in men casting cadmium alloys. Br. J. Ind. Med. 12: 181-191.

Bremner, I. 1974. Heavy metal toxicities. Q. Rev. Biophys. 7: 75-124.

Carroll, R.E. 1966. The relationship of cadmium in the air to cardiovascular disease death rates. JAMA 198: 267-269.

Chattopadhyay, A., T. Roberts and R. Jervis. 1977. Scalp hair as a monitor of community exposure to lead. Arch. Environ. Health 32: 226-236.

Cheftel, H., et al. 1972. Evaluation of certain food additives and the contaminants mercury, lead, and cadmium. World Health Organization, Tec. Rep. Ser. 505: 20-24, 32.

Cherian, M.G. and R. Goyer. 1978. Role of metallothioneins in disease. Ann. Clin. Lab. Sci. 8: 91-94.

Chernoff, N. 1973. Teratogenic effects of cadmium in rats. Teratology $8(1): 29-32$.

Chittleborough, G. 1980. A chemist's view of the analysis of human hair for trace elements. Sci. Total Environ. 14:53-75.

Clarkson, T.W. and J. Kench. 1956. Urinary excretion of amino acids by men absorbing heavy metals. Biochem. J. 62: 361-372.

Cook, J.A., E. Hoffman and N. Luzio. 1975. Influence of lead and cadmium on the susceptibility of rats to bacterial challenge. Proc. Soc. Exp. Biol. Med. 150: 741-747. 
Cornelius, R. 1973. Neutron activation analysis of hair: failure of a mission. J. Radioanal. Chem. 15: 305-316.

Deeming, S.B. and C. Weber. 1977. Evaluation of hair analysis for determination of zinc status using rats. Am. J. Clin. Nutr. 30: 2047-2052.

Doyle, J.J., R. Bernhoft and H. Sandstead. 1975 . The effects $8 f$
a low level of dietary cadmium on blood pressure, $24 \mathrm{Na},{ }^{\mathrm{K}}$ and water retention in growing rats. J. Lab. Clin. Med. 86: $57-63$.

Duggan, R.E. and P. Corneliussen. 1972. Dietary intake of pesticide chemicals in the United States (III), June 1968-April 1970. Pestic. Monit. J. 5: 331-343.

Durbin, P.W., K. Scott and J. Hamilton. 1957. The distribution of some heavy metals in the rat. Univ. Calif. Publ. Pharmacol. 3: $1-12$.

Eads, E. and C. Lambdin. 1973. A survey of trace metals in human ha ir. Environ. Res. 6: 247-252.

Ear1, F.L. and T. Vish. 1979. Teratogenicity of heavy metals. In Oehme, F.W. (Ed.). Toxicity of heavy metals in the environment, II. Marcel Dekker, N.Y. Pp. 617-639.

Ediger, R.D. and R. Coleman. 1973. Determination of cadmium in blood by a Delves cup technique. Atomic Absorp. News1. 12: 3-6.

Ellis, K.J., et a1. 1979. Cadmium: in vivo measurement in smokers and nonsmokers. Sci. 205: 323-325.

Epstein, E. 1972. Mineral nutrition of plants: principles and perspectives. John Wiley and Sons, New York. 412pp.

Epstein, S.S., et al. 1972. Determination of chemical mutagens by dominant lethal assay in the mouse. Toxicol. Appl. Pharmacol. 23: $288-325$.

Evans, G.W., P. Majors and W. Cornatzer. 1970. Mechanism for cadmium and zinc antagonism of copper metabolism. Biochem. Biophys. Res. Comm. 40: 1142-1148.

Fassett, D.W. 1972. Cadmium. In Lee, D.H.K. (Ed.). Metallic contaminants and human health. Academic Press, N.Y. Pp. 97-124.

and D. Irish (Eds.). 1978. Toxicology. Patty's industrial hygiene and toxicology, II. Interscience, N.Y. 2,481pp.

Feldman, S.L. and R. Cousins. 1973. Inhibition of 1,25-dihydroxycholecalciferol synthes is by cadmium in vitro. Fed. Proc. 32: 918. 
Ferm, V.H., D. Hanlon and J. Urban. 1969. The permeability of the hamster placenta to radioactive cadmium. J. Embryol. Exp. Morph. 22(1): 107-113.

Flick, D.F., H. Kraybill and J. Dimitroff. 1969. Toxic effects of cadmium: a review. Environ. Res. 4: 71-85.

Friberg, L. 1948. Proteinuria and kidney injury among workmen exposed to cadmium and nickel dust. J. Ind. Hyg. Toxicol. 30:32-36.

, et a1. 1974. Cadmium in the environment. CRC Press, Cleveland. 248pp.

Fullmer, C.S., T. Oku and R. Wasserman. 1980. Effect of cadmium administration on intestinal calcium absorption and vitamin D-dependent calcium-binding protein. Environ. Res. 22: 386-399.

Gauch, H. 1972. Inorganic plant nutrition. Dowden, Hutchinson \& Ross, Stroudsberg, PA. 488pp.

Griffiths, P.R. 1980. Morphological and ultrastructural effects of sublethal cadmium poisoning on Daphnia. Environ. Res. 22: 277-284.

Gunn, S.A., T. Gould and W. Anderson. 1963. Cadmium-induced interstitial cell tumors in rats and mice and their prevention by zinc. J. Nat. Cancer Inst. 31: 745-753.

. 1967. Specific response of mesenchymal tissue to cancerigenes is by cadmium. Arch. Path. 83: $493-499$.

- 1968. Specificity in protection against lethality and testicular toxicity from cadmium. Proc. Soc. Exp. Biol. Med. 128: 591-595.

Hammer, D.I., et al. 1971. Hair trace metal levels and environmental exposure. Am. J. Epidemiol. 93: 84-92.

Harrison, W., J. Yurachek and C. Benson. 1969. The determination of trace elements in human hair by atomic absorption spectroscopy. Clin. Chim. Acta 23: 83-91.

Heath, J.C., et a1. 1962. Cadmium as a carcinogen. Nature 193: 592-593.

Hickey, R.J., E. Schoff and R. Clelland. 1967. Relationship between air pollution and certain chronic disease death rates. Arch. Environ. Health 15: 728-738. 
Hoagland, D.R., W. Chandler and P. Hibbard. 1936. Little-leaf or rosette of fruit trees $V$. Effect of zinc on the growth of plants of various types in controlled soil and water culture experiments. Proc. Amer. Soc. Hort. Sci. 33: 131-141.

Holden, H. 1965. Cadmium fume. Ann. Occup. Hyg. 8: 51-54. - 1969. Cadmium toxicology. Lancet 2: 57.

Hopps, H.C. 1977. The biologic bases for using hair and nail for analyses of trace elements. Sci. Total Environ. 7: 71-89.

Hunt, W.F., et al. 1971. A study in trace element poliution of a ir in 77 midwestern cities. Trace Subst. in Environ. Health 4: 56-67.

Hunter, D. 1969. The diseases of occupations. 4th ed. Little, Brown and Co., Boston. 1259pp.

Hurshman, L.G., B. Brown and R. Guyton. 1978. The implications of sidestream cigarette smoke for cardiovascular health. J. Environ. Health 41: 145-149.

Klevay, L.M. 1970. Hair as a biopsy material I. assessment of zinc nutriture. Am. J. C1 in. Nutr. 23: 284-289.

- 1978. Hair as a biopsy materia 1: progress and prospects. Arch. Intern. Med. 138: 1127-1128.

Kollmer, W.E. and D. Berg. 1979. Interrelations between hair content, intravenous dose and retention of $\mathrm{Cd}$ in different rat-tissues. J. Radioanal. Chem. 52: 189-197.

Kopito, L., R. Byers and H. Shwachman. 1967. Lead in hair of children with chronic lead poisoning. New Eng. J. Med. 276: 949-953.

Kubota, J., V. Lazar and F. Losee. 1968. Copper, zinc, cadmium and lead in human blood from 19 locations in the United States. Arch. Environ. Health 16: 788-793.

Lauwerys, R.R., et al. 1974. Epidemiological survey of workers exposed to cadmium. Effect on lung, kidney and several biological indices. Arch. Environ. Health 28: 145-148.

Lemen, R.A., et a1. 1976. Morality among workers exposed to cadmium. Ann. N.Y. Acad. Sci. 271: 273-279.

Lewis, G.P., H. Lyle and S. Miller. 1969. Association between elevated hepatic water-soluble prote in-bound cadmium levels and chronic bronchitis and/or emphysema. Lancet 2: 1330-1333. 
, et a1. 1972. Cadmium accumulation in man: influence of smoking, occupation, alcohol ic habit and disease. J. Chron. Dis. 25: 717-726.

Loose, L.D., J. Silkworth and D. Warrington. 1977. Cadmium-induced depression of the respiratory burst in mouse pulmonary alveolar macrophages, peritoneal macrophages and polymorphonuclear neutrophils. Biochem. Biophys. Res. Commun. 79: 326-332.

Maugh, T.H. 1978. Hair: a diagnostic tool to complement blood serum and urine. Sci. 202: 1271-1273.

McBean, L.D., et a1. 1971. Correlation of zinc concentrations in human plasma and hair. Am. J. Clin. Nutr. 24: 506-509.

McKenzie, J.M. 1979. Content of zinc in serum, urine, hair, and toenails of New Zealand adults. Am. J. Clin. Nutr. 32: 570-579.

Menden, E.E., et a1. 1972. Distribution of cadmium and nickel of tobacco during cigarette smoking. Environ. Sci. Technol. 6: $830-832$.

Mitra, R.S. and I. Bernstein. 1978. Single-strand breakage in DNA of Escherichia col $i$ exposed to $\mathrm{Cd}^{27}$. J. Bacteriol. 133: 75-80.

Moore, $W_{\text {. }}$, et a1. 1973. Comparison of $115 \mathrm{~m}_{\text {Cadmium retention in rats }}$ following different routes of administration. Environ. Res. $6: 473-478$.

Morgan, J.M. 1969. Tissue cadmium concentration in man. Arch. Intern. Med. 123: 405-408.

Müller, S., et a1. 1979. Effects of cadmium on the immune system of mice. Experientia 35: 909-910.

Nandi, M., et al. 1969. Cadmium content of cigarettes. Lancet 2: 1329-1330.

Nogawa, K., et al. 1980. Renal dysfunctions of inhabitants in a cadmium-polluted area. Environ. Res. 23: 13-23.

Nomiyama, K. 1980. Recent progress and perspectives in cadmium health effects studies. Sci. Total Environ. 14: 199-232.

Nordberg, G., L. Friberg and M. Piscator. In Friberg, L., M. Piscator and G. Nordberg. 1971. Cadmium in the environment. CRC Press, Cleveland. Pp. 30, 44.

Nordberg, G.F. and K. Nishiyama. 1972. Whole-body and hair retention of cadmium in mice. Arch. Environ. Health 24: 209-214. 
Nordberg, M. 1978. Studies on metallothione in and cadmium. Environ. Res. 15: 381-404.

Obrusnik, I., et a1. 1972. The variation of trace element concentrations in single human head hairs. J. Forensic Sci. 17: 426-439.

- 1973. The variation of trace element concentrations in single human head hairs. J. Radioana 1. Chem. 15: 115-133.

Ochiai, E. 1977. Bioinorganic chemistry: an introduction. Allyn and Bacon, Boston. 515pp.

Oleru, U.G. 1975. Epidemiological implications of environmental cadmium I. the probable utility of human hair for occupational trace metal (cadmium) screening. Am. Ind. Hyg. Assoc. J. 36: 229-233.

- 1976. Kidney, liver, hair and lungs as indicators of cadmium absorption. Am. Ind. Hyg. Assoc. J. 37: 617-621.

Ostergaard, K. 1978. Renal cadmium concentration in relation to smoking habits and blood pressure. Acta Med. Scand. 203: 379-383.

Peereboom-Stegeman, J.H., et a1. 1979. Influence of chronic Cd intoxication on the alkaline phosphatase activity of liver and kidney; biochemical, histochemical and histological investigations. Toxicol. 14: 67-80.

Perkons, A.K. and R. Jervis. 1966. Trace elements in human head hair. J. Forensic Sci. 11: 50-63.

Perry, H.M., et a1. 1967. Mechanisms of the acute hypertensive effect of intra-arterial cadmium and mercury in anaesthetized rats.

J. Lab. C1 in. Med. 70: 963-972.

and M. Erlanger. 1973. Elevated circulating renin activity in rats following doses of cadmium known to induce hypertension. J. Lab. Clin. Med. 82: 399-405.

, et a1. 1980. Inhibition of cadmium-induced hypertension in rats. Sci. Total Environ. 14: 153-166.

Petering, H.G., M. Johnson and K. Stemmer. 1971a. Studies of zinc metabolism in the rat 1 . dose-response effects of $\mathrm{Cd}$. Arch. Environ. Health 23: 93-101.

D. Yeager and S. Witherup. 1971b. Trace metal content of hair I. zinc and copper content of human hair. Arch. Environ. Health 23: 202-207. 
Petering, H.G., D. Yeager and S. Witherup. 1973. Trace metal content of hair II. cadmium and lead of human hair. Arch. Environ. Health 27: 327-330.

Potts, C.L. 1965. Cadmium prote inuria--the health of battery workers exposed to cadmium oxide. Ann. Occup. Hyg. 8: 55-61.

Prasad, A.S., et a1. 1963. Zinc metabolism in patients with the syndrome of iron deficiency anemia, hepatosplenomegaly, dwarfism, and hypogonadism. J. Lab. C1 in. Med. 61: 537-549.

(Ed.). 1976. Trace elements in human health and disease. II. Essential and toxic elements. Academic Press, N.Y. 525pp.

Pringle, B., et al. 1968. Trace metal accumulation by estuarine molluscs. J. Sanit. Eng. Div. Proc. Am. Soc. Civ. Eng. 94: $455-461$.

Reinhold, J.G., et a1. 1966. Zinc and copper concentrations in hair of Iranian villagers. Am. J. Clin. Nutr. 18: 294-300.

Rendic, D., et a1. 1976. Trace-element concentrations in human hair measured by proton-induced X-ray emission. J. Invest. Dermatol. 66: $371-375$.

Revis, N. 1977. A possible mechanism for cadmium-induced hypertension in rats. Life Sci. 22: 479-488.

Ribas-Ozonas, B., M. Guelbenzu and A. Ruiz. 1971. Inhibitory effect of cadmium on alkaline phosphatase of kidney and prostate of guinea pig. In C.F. Mills (Ed.) Trace element metabolism in animals. E. and E. Livingston, Edinburgh. Pp. 173-176.

Schroeder, H.A. and W. Vinton. 1962. Hypertension induced in rats by small doses of cadmium. Am. J. Physiol. 202: 515-518. 207: 62-66.

1964a. Cadmium hypertension in rats. Am. J. Physiol.

- 1964b. Renal cadmium and essential hypertension.

JAMA 187: 358.

, J. Balassa and W. Vinton. 1964c. Chromium, lead, cadmium, nickel and titanium in mice: effect on mortality, tumors and tissue levels. J. Nutr. 83: 239-250.

and J. Buckman. 1967a. Cadmium hypertension: its reversat in rats by a zinc chelate. Arch. Environ. Health 14: 693-697. 
Schroeder, H.A., et al. 1967b. Essential trace metals in man: zinc. Relation to environmental cadmium. J. Chron. Dis. 20: 179-210.

and A. Nason. 1969. Trace metals in human hair. J. Invest. Dermato 1. 59: 71-78.

and M. Mitchener. 1971. Toxic effects of trace element on the reproduction of mice and rats. Arch. Environ. Health 23: $102-106$.

Shaikh, Z. and 0. Lucis. 1972a. Biological differences in cadmium and zinc turnover. Arch. Environ. Health 24: 410-425.

- 1972b. Cadmium and zinc binding in mammalian Tiver and kidneys. Arch. Environ. Health 24: 419-425.

Sharrett, A.R. 1977. Water hardness and cardiovascular disease elements in water and human tissues. Sci. Total Environ. 7: $217-226$.

Shimkin, M.B., G. Stoner and J. The iss. 1978. Lung tumor response in mice to metals and metal salts. In Schrauzer, G.N. (Ed.) Inorganic and nutritional aspects of cancer. Plenum Press, N.Y. Pp. 85-91.

Sissoeff, I., J. Grisvard and E. Guille. 1976. Studies on metal ionsDNA interactions: specific behavior of reiterative DNA sequences. Prog. Biophys. Mol. Biol. 31: 165-199.

Smith, J.C. and E. Brown. 1976. Effects of oral contraceptive agents on trace element metabolism--a review. In Prasad, A.S. (Ed.) Trace elements in human health and disease. V II. Essential and toxic elements. Pp. 315-345.

Strain, W.H., et al. 1966. Analys is of zinc levels in hair for the diagnosis of zinc deficiency in man. J. Lab. Clin. Med. 68: 244-249.

Suzuki, K.T. and M. Yamamura. 1981. Native and induced rat kidney metallothioneins and their relation to cadmium toxicity. Arch. Environ. Contam. Toxicol. 10: 251-262.

Suzuki, S., T. Suzuki and M. Ashizawa. 1965. Proteinuria due to inhalation of cadmium stearate dust. Ind. Health 3: 73-79.

Thomas, R., J. Wilson and J. London. 1980. Multispecies retention parameters for cadmium. Environ. Res. 23: 191-207.

Tipton, I.H. and M. Cook. 1963. Trace elements in human tissue. II. Adult subjects from the United States. Health Phys. 9: 103-145. 
Tipton, I.H. and P.L. Stewart. 1970. Patterns of elemental excretion in long-term balance studies II. Health Phys. Div. Ann. Progr. Rep. ORNL-4446: 303-314.

Travis, C.C. and A. Haddock. 1980. Interpretation of the observed age-dependency of cadmium body burdens in man. Environ. Res. 22: $46-60$.

Underwood, E.J. 1971. Trace elements in human and animal nutrition. 3rd ed. Academic Press, N.Y. 543pp.

- 1979. Interactions of trace elements. In Toxicity of heavy metals in the environment. Pt. 2. Marcel Dekker, N.Y. Pp. 641-668.

U.S. Department of Health, Education, and Welfare. 1977. Occupational diseases: a guide to the ir recognition. DHEW Publ. 77-181. U.S. Government Printing Office, Washington, D.C. 608pp. . 1979. Smoking and health. U.S. Government Printing Office, Washington, D.C. n.p.

Welinder, H., S. Skerfving and 0. Henriksen. 1977. Cadmium metabolism in man. Br. J. Ind. Med. 34: 221-228.

Yurachek, J., G. Clemena and W. Harrison. 1969. Analys is of human hair by spark source mass spectrometry. Anal. Chem. 37: 1666-1668. 
APPENDICES 
APPENDIX A

PREVIOUS STUDIES ON Cd AND Zn IN HUMAN HAIR

\begin{tabular}{|c|c|c|c|}
\hline Subjects & $\begin{array}{c}\text { Concentration }{ }^{1} \\
(\mu \mathrm{g} / \mathrm{g})\end{array}$ & $\begin{array}{l}\text { Analysis } \\
\text { Techn ique }^{2}\end{array}$ & Reference \\
\hline $\begin{array}{l}\text { ? Americans } \\
66 \text { rural Canadians } \\
45 \text { urban Canadians } \\
82 \text { U.S. males } \\
18 \text { Port Arthur, TX males } \\
95 \text { Cincinatti, OH males } \\
47 \text { U.S. females } \\
21 \text { Port Arthur, TX females } \\
83 \text { Cincinatti, OH females }\end{array}$ & $\begin{array}{c}0.34--1.8 \\
1.2 \mathrm{M}(0.25--2.7) \\
2.0 \mathrm{M}(0.32--3.4) \\
2.76 \pm .483 \\
2.2(0.1--9.3) \\
2.2 \pm .2 \\
1.77 \pm .239 \\
1.0(0.2--3.6) \\
2.43 \pm .26\end{array}$ & $\begin{array}{l}\text { SSMS } \\
\text { PAA } \\
\text { " } \\
\text { AAS } \\
" \\
" \\
" \\
"\end{array}$ & $\begin{array}{l}\text { Yurachek et al. } 1969 \\
\text { Chattopadhyay et al. } 1977 \\
\text { Chattopadhyay et al. } 1977 \\
\text { Schroeder } 1969 \\
\text { Eads et al. } 1973 \\
\text { Petering et al. } 1973 \\
\text { Schroeder } 1969 \\
\text { Eads et al. 1973 } \\
\text { Petering et al. } 1973\end{array}$ \\
\hline $\begin{array}{l}33 \text { Oak Ridge, Tennesseans } \\
\text { ? Canadians } \\
12 \text { Egyptians } \\
3 \text { ? U.S. subjects } \\
75 \text { Iranian children aged } 6-12 \\
4 \text { Egyptian males } \\
33 \text { Hastings, N.Z. schoolboys } \\
33 \text { Napier, N.Z. Schoolboys } \\
20 \text { Iranian male students } \\
6 \text { New York male adults } \\
18 \text { U.S. male adults } \\
82 \text { U.S. males } \\
64 \text { Panamanian male adults } \\
14 \text { Washington, D.C. male adults } \\
\text { C. 100 Cincinatti, OH males } \\
18 \text { Port Arthur, TX males } \\
42 \text { New Zealand males aged 18-27 } \\
16 \text { Iranian female adults } \\
47 \text { U.S. females } \\
70 \text { Panamanian female adults } \\
\text { C. 100 Cincinatti, OH females } \\
21 \text { Port Arthur, TX females } \\
54 \text { New Zealand females }\end{array}$ & $\begin{array}{c}177 \pm 73^{D} \\
300--1000 \\
103.3 \pm 4.9 \\
143--246 \\
199 \pm 22^{D} \\
105 \cdots-136 \\
126 \pm 14{ }^{D} \\
132 \pm 15 D \\
181 \pm 36.3^{D} \\
119.6 \pm 4.6 \\
178.7(143--206) \\
167.0 \pm 5.09 \\
142 \pm 43 D \\
176 \pm 37 D \\
147 \\
156(75--454) \\
180 \pm 25 \\
268 \pm 59.3 D \\
172.1 \pm 9.32 \\
167 \pm 129 D \\
153 \\
173(65--308) \\
195 \pm 23\end{array}$ & $\begin{array}{l}\text { NAA } \\
\text { AES } \\
\text { SSMS } \\
\text { AAS } \\
\text { NAA } \\
\text { " } \\
\text { Z/D } \\
\text { AES } \\
\text { AAS } \\
" 1 \\
" \\
" \\
" \\
" \\
\text { Z/D } \\
\text { AAS } \\
" \\
" \\
" \\
"\end{array}$ & $\begin{array}{l}\text { Bate \& Dyer } 1975 \\
\text { Perkons \& Jervis } 1966 \\
\text { Strain et al. } 1966 \\
\text { Yurachek et al. } 1969 \\
\text { McBean et al. } 1971 \\
\text { Prasad et al. } 1963 \\
\text { Bate \& Dyer } 1965 \\
\text { Bate \& Dyer 1965 } \\
\text { Reinhold et al. } 1966 \\
\text { Strain et a . 1966 } \\
\text { Harrison et al. } 1969 \\
\text { Schroeder } 1969 \\
\text { Klevay } 1970 \\
\text { McBean et al. } 1971 \\
\text { Petering et al. } 1971 \\
\text { Eads et al. } 1973 \\
\text { McKenzie } 1979 \\
\text { Reinhold et al. } 1966 \\
\text { Schroeder } 1969 \\
\text { Klevay } 1970 \\
\text { Petering et al. } 1971 \\
\text { Eads et al. } 1973 \\
\text { McKenzie } 1979\end{array}$ \\
\hline
\end{tabular}

1 Concentrations are average \pm standard error uniess noted (D) as standard deviation; if means were not reported medians $(M)$ and/or ranges are given.

2 AAS = Atomic absorption spectroscopy

AES = Atomic emission spectroscopy

$N A A=$ Neutron activation analysis

$P A A=$ Photon activation analys is

SSMS = Spark source mass spectroscopy

$Z / D=$ Zincon/Dithizone analysis 


\section{APPENDIX B}

INFORMED CONSENT

I, hereby agree to serve

as a subject in the research project on cadnilum conducted by Neal Simonsen.

I understand that the study involves the donation of a sample of scalp hair for trace metal analysis and candid completion of a background questionnaire by each subject.

I understand the possible risks and discomforts to me associated with this study, including a demand on my tine and effort inrolved in the filling out of the study questionnaire as well as the inconvenience of collecting and tagging a sample of scalp hair.

It has been explained to me that the purpose of this study is to explore the differences in levels of cadmium (and zinc) in the hair of individuals in the population as they relate to smoking habits. I may not receire any direct benefit from participating in this study, but my participation may help to increase knowledge which may benefit others in the future. Neal Simonsen has offered to answer any questions I may have about the study and what is required of the in the study.

I understand that I am free to withdraw from participation in this study at any time without jeopardizing relationship with Portland State Iniversity.

I have read and understand the foregoing information. Date Signature 
Number

1. Age (in years at last birthday):

We1ght:

Height:

2. Sex:
a Male
b Female

3. Race:
a White (non-H1 spanic)
b Black
c Asian or Pacific Islander
d Hispanic
e Other (please spectfy)

4. Natural predominant hatr color:
a Brown
b Black
c Blond
d Red
e Grey or white

5. Do you or have you smoke(d) tobacco? (Check Yes or No; if Yes please also answer 1 , ii, iif, iv and $v$ below)
a Yes
1 Do you or did you smoke: (Check all which apply)
a Cigarettes
b Cigars
c A pipe
if Are you a ourrent or only a former smoker?
a Current
b Former
111 How many years have you or did you smoke(d)?:
Iv If you are or were a cigarette smoker, how many packs per day do you or did you smoke, on the average?:
$\nabla$ If you are or were a cigarette smoker and smoke(d) one
b No brand most of the time, which brand 1s or was it?:

6. Do you or did you smoke marijuana? (Check Yes or No; $1 f$ Yes please answer 1, 11 and 111)

a Yes

1 Are you a current or only a former smoker?

a Current

b Former

1i How many years have you or did you smoke(d)? :

111 If you are or were a marijuana smoker, about how many

b No days per month do you or did you smoke it, on the average?:

7. What is the ilp code of your place of residence?:

8. Are there any major refineries, smelters or other metal or chemical industrial complexes within a mile of the place? (If Yes, please list in space provided)

a Yes:

b No

c Don't know 
9. If there are any other areas you regulariy spend 30 hours per week or more in, please locate them by listing their 2ip codes:

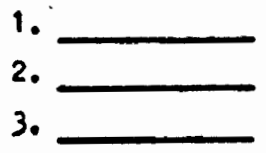

10. Are there any najor refineries, smelters or other industrial complexes in these areas? (If unsure, answer No)
a Yes, in area 1.
b Yes, in area 2.
c Yes, in area 3.
d No

11. Are you regularly exposed to other people's tobacco smoke at home, work or otherwise?

a Yes, for more than 5 hours per week

b Yes, for 5 hours or less per week

c No

12. Do you do any soldering work at home or at your job?

a Yes

b No

13. Are you a vegetarian?

a Yes

b No

14. Which of the following items are a part of your diet at least once a week, on the average? (Check all which apply)
a Fish
b Anchovies
c Shellfish
d Oysters
e Rice

15. Do you drink at least two cups of tea a week, on the average?
a Yes
b No

16. What hair care products do you use? (Please list)

17. How of ten do you wash your hair, on the average?

a 4 or more times per week

b 3 times or less per week

18. Do you use oral contraceptives?
a Yes
b No

19. Do you have any chronic conditions (such as asthma or hay fever) or current illnesses (such as the flu or strep throat)?
a Yes
b No

If Yes, please Iist: 


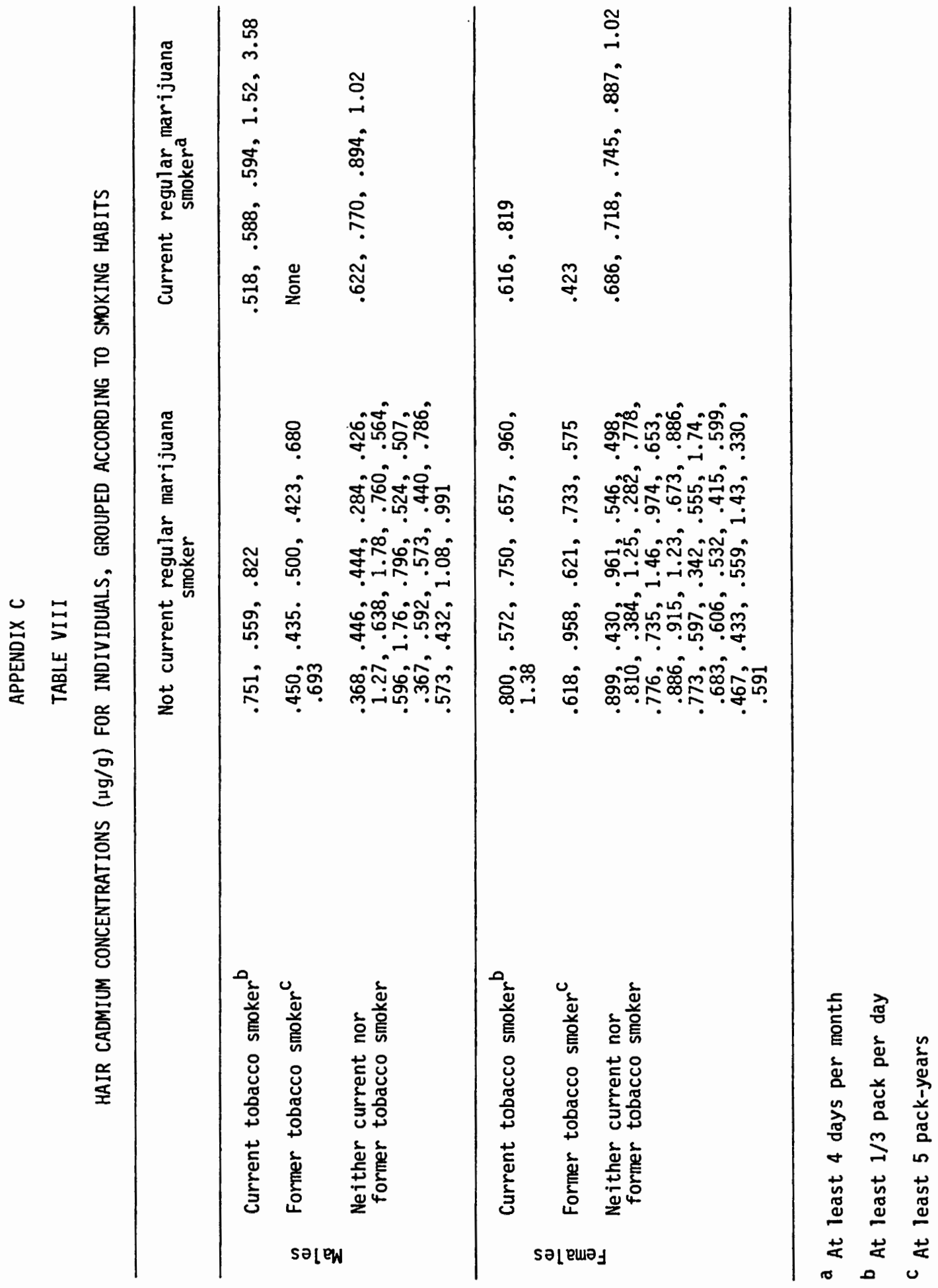




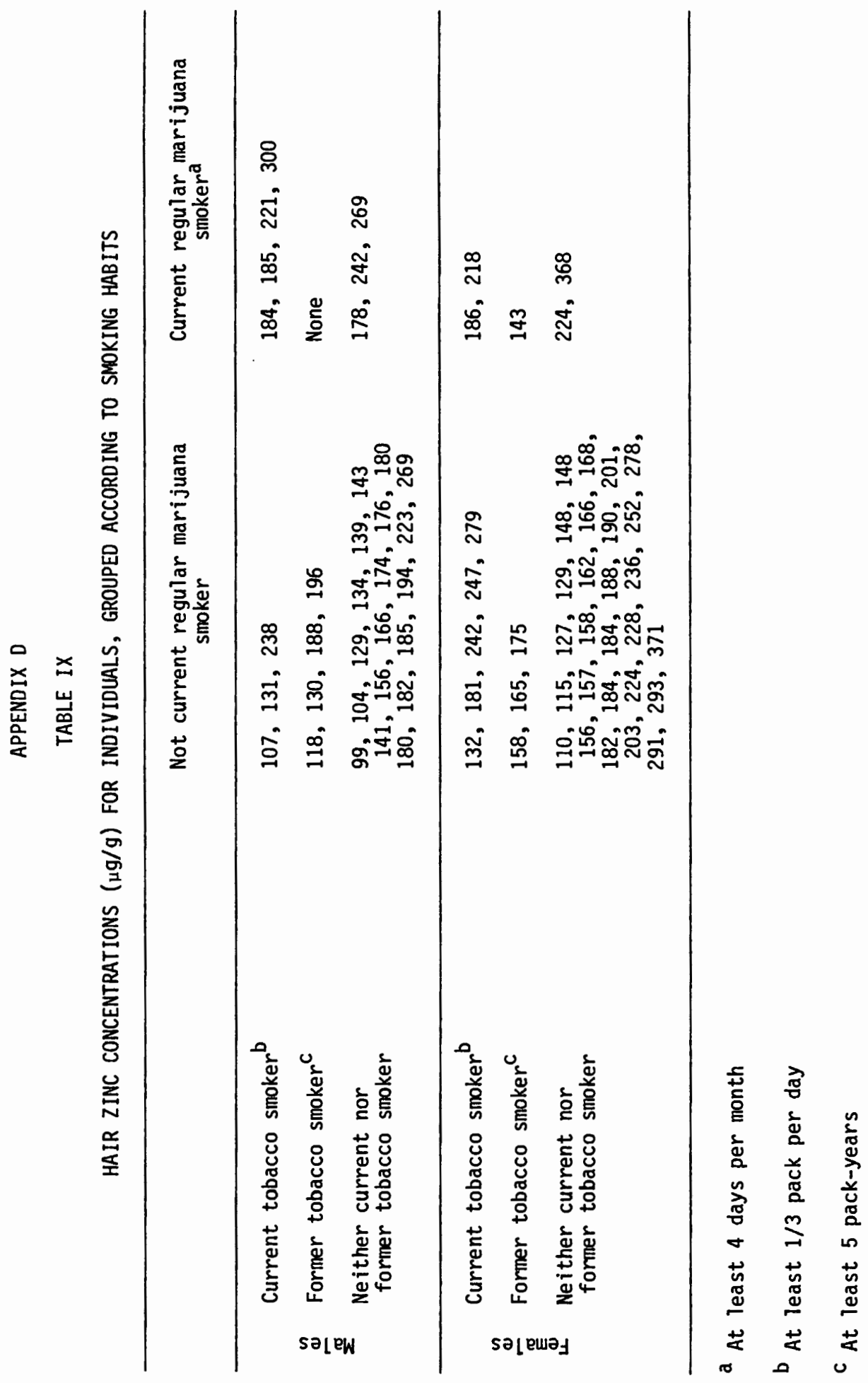




\section{APPENDIX E}

SUMMARY OF SELECTED QUESTIONNAIRE RESPONSES - MAIN STUDY

Average age: 25.8 years

Sex:

$\begin{array}{ll}\text { Male } & 43 \% \\ \text { Female } & 57 \%\end{array}$

Race :

White
Black
Asian or Pacific Islander
Hispanic

\begin{tabular}{cc} 
Males & Females \\
\cline { 1 - 2 } $93 \%$ & $96 \%$ \\
-5 & -- \\
2 & 4 \\
--
\end{tabular}

Natural predominant hair color:

Brown

Black

Blonde

Red

Grey or white

17

21

67

Grey or white

Do or did smoke tobacco

52

--

Do or did smoke marijuana

Regularly exposed to other people's tobacco smoke:

5 or more hours per week

Less than 5 hours per week

Not regularly exposed

Vegetarian

Eat at least once per week:

Fish

Anchovies

Shellfish

Oysters

Rice

Drink $2+$ cups tea/week

Wash hair more than 3 times per week

Use oral contraceptives

Chronic conditions, current illness:

Hay fever or "allergy"

Recent flu or cold

Asthma

Strep throat

UTcers

Kidney infection
33

3

$--$

$--$

38

23

85

51

39

-.-

35

$-$

$--$ 